\title{
Szülői felügyeleti jog, kapcsolattartás és tartásdíffizetés a különélő magyar szülők gyakorlatában ${ }^{1}$
}

\author{
Szalma Ivett - Rékai Krisztina² \\ https://doi.org/10.51624/SzocSzemle.2019.4.4 \\ Beérkezés: 2019. 10. 04. \\ Átdolgozott változat beérkezése: 2019. 12. 11. \\ Elfogadás: 2019. १२. २०.
}

\begin{abstract}
Összefoglaló: Jelentős változások következtek be a családok életében az utóbbi évtizedekben Magyarországon: válások és élettársi kapcsolatok egyre nagyobb arányban bomlanak fel, miközben az apák szerepvállalása is változóban van: egyre nagyobb részt vállalnak a gyermekek életében mind instrumentális, mind emocionális szempontból. Jelen tanulmány célja, hogy megvizsgálja, hogy a különélő szülők (többnyire apák) miként vesznek részt gyermekeik életében, illetve hogyan valósul meg a szülői felügyeleti jog, a láthatóság és a tartásdíjfizetés a gyakorlatban. Ennek szociológiai vizsgálata azért is fontos, mert eddig nem került sor hasonló elemzésére, valamint Magyarországon 2014-ben életbe lépett az új Polgári Törvénykönyv, amely jelentős változásokat hozott a szülői felügyeleti jog és a tartásdíjfizetés szabályozásában.
\end{abstract}

Kulcsszavak: felügyeleti jog, kapcsolattartás, tartásdíj, különélő apák szerepe, félig strukturált interjúk

\section{Bevezetés}

A 21. században a nemi szerepekhez hasonlóan a tradicionális szülöi szerepek is elkezdtek átalakulni, és ezzel új teret nyitottak a törődő apaság elterjedéséhez, azaz amikor az apák a fizetett munkavégzés mellett a gyermekekkel való törődésből is egyaránt kiveszik a részüket (Dermott-Miller 2015). Ennek köszönhetően egyre több apa vállal aktív részt a gazdasági ellátáson túl gyermekei érzelmi gondozásában is. Az apaszerepek változásait Magyarországon is elemezték: például Spéder (2011) a 2009-es Családi értékek címú adatbázist vizsgálva arra a következtetésre jutott, hogy a mai apáknak ellentmondó elvárásoknak kell megfelelniük. Ez azt jelenti, hogy egyrészt a társadalom továbbra is elvárja tőlük, hogy elsődleges kenyérkeresők legyenek, miközben azzal az elvárással is

1 A tanulmány a Bolyai János Kutatási Ösztöndijj támogatásával, valamint az Innovációs és Technológiai Minisztérium ÚNKP-194-BCE-11 kódszámú Új Nemzeti Kiválóság programjának szakmai támogatásával készült.

A szerzők szeretnének köszöntetet mondani Tóth Adélnak az interjúkészitésben való közremüködéséért.

2 A tanulmány elkészítését a TK Szociológiai Intézetének - Magyar Tudományos Akadémia Kiváló Kutatóhely - gyakornoki programja tette lehetővé. 
szembesülnek, hogy aktívabban kell részt venniük a család érzelmi életében és a gyermekek körüli gyakorlati feladatokban is, mint korábban. Takács Judit (2017, 2019) interjús vizsgálata pedig arra világított rá, hogy nemcsak társadalmi elvárás az apák felé, hogy nagyobb gyakorlati szerepet vállaljanak a gyermekek életében, hanem ők maguk is szeretnének mindinkább aktívan részt venni a gyermeknevelésben a korábbi generációkhoz képest. Ennek ellenére egy survey adatokon végzett kutatás (Szalma 2014) azt találta, hogy Magyaraországon a kérdezettek közel 30\%-a nem ért egyet azzal az állítással, hogy az apák éppúgy képesek gondoskodni gyermekeikről, mint az anyák.

Miközben mind a nemzetközi, mind a hazai kutatások rávilágítottak arra, hogy az apaszerepek változóban vannak - az apák szerepének növekedése figyelhető meg a családi életben -, ugyanakkor egyre több olyan családdal találkozhatunk, ahol a biológiai apa nem él együtt a gyermekével válás vagy az élettársi kapcsolatok felbomlása miatt (Makay-Szabó 2018). Az egyszülős családok aránya 1970-ben 9,1\% volt, 1990-ben 12,3\%, és 2011-ben 19,8\%-ra emelkedett (Kapitány 2015). Azonban nem érdemes az egyszülős családokra statikus intézményként tekintenünk, hiszen a jelenség sokszor csak átmenetinek tekinthető, mivel a mozaikcsaládok kialakulása is egyre gyakoribb - azaz amikor létrejön egy olyan újraformálódott közösség, ahol az egyik szülő már nem él a családdal, viszont új partner és esetleg annak gyermeke érkezik a háztartásba (Murinkó-Szalma 2015, 2016). Ez azonban magába foglalhatja azt is, hogy időlegesen akár több gyermek tapasztalhatja meg az egyszülős családban élést, mint a keresztmetszeti statisztikák adatai. Például Monostori Judit (2015) 2001 és 2012 között az Életünk fordulópontjai adatbázison vizsgálta az 1971 és 1983 között született anyák életútját, és azt találta, hogy az anyák 39\%-a nevelte már időlegesen egyedül 18 év alatti gyermekét. Magyarországon az egyszülős családok 87\%-ában az anya neveli a gyermekeket, miközben az egyszülős családok 13\%-ánál az anya hiányzott a családból 2011-ben (Monostori 2019). Ugyanakkor Magyarországon is egyre többször előfordul, hogy a szülők megosztva nevelik a gyermekeket a párkapcsolat felbomlása után. A KSH számításai szerint (2019) a felbontott és érvénytelenített házasságok esetén, ahol a közös kiskorú gyermekek érintettek, 1995-ben a szülópárok 3,3\%-a választotta a megosztott gyermekelhelyezést, míg ugyanez az arány 2017-ben 13,6\%-ra nőtt. Nyilvánvalóan számos feltételnek teljesülnie kell ahhoz, hogy a szülők megosztva tudjanak a gyermekeikről gondoskodni. Ilyen feltétel lehet például, hogy a szülők kommunikáljanak és együttmúködjenek egymással, ne éljenek egymástól távol, és mindkét szülő rendelkezzen megfelelő anyagi háttérrel ahhoz, hogy a gyermek vele élhessen.

Az egyszülős családok helyzete azért is érdemel kitüntetett figyelmet, mert körükben a szegénységi kockázat sokkal magasabb, mint a kétszülős családok körében. Az EU-SILC 2010-es statisztikája kimutatta, hogy az egyszülős háztartásban való felnövekedés nagyobb mértékben járul hozzá a gyermekszegénységhez Magyarországon, mint három vagy több gyermek nevelése tradicionális, kétszülős családban (Monostori 2019). Mivel az egyszülős családok többsége a párkapcsolat felbomlá- 
sa révén jön létre (Földházi-Murinkó 2012), így a tartásdíj rendszeres és megfelelő mértékű fizetése csökkenthetné a szegénységi kockázatot az egyszülős családok jelentős részénél (Monostori 2019). Azonban az OECD Child Support jelentése (OECD 2010) rávilágított arra, hogy ennek gyakorlati megvalósulása korántsem ideális, ami számos rendszerszintű és társadalmi problémára utalhat. Hasonló eredményt talált Monostori (2019), aki a 2016-os Életünk fordulópontjai adatbázis adatai alapján azt állapította meg az elvált szülők által nevelt 18 év alatti gyermekekkel kapcsolatban, hogy mindössze 57\%-uk után fizetnek a különélő szülők tartásdíjat.

Magyarországon korábban még kvalitatív úton nem vizsgálták azt, hogy a különélő apák miként vesznek részt a gyermekek életében, hogyan támogatják ôket anyagilag, illetve érzelmileg, és hogy milyen tényezők befolyásolhatják a különélő apa és gyermeke közötti kapcsolattartást. Jelen kutatás célja, hogy megvizsgálja a tartásdíj fizetésének, a szülői felügyeleti jogok gyakorlásának és a kapcsolattartásnak gyakorlati megvalósítását. Továbbá szeretnénk azt is megérteni, hogy milyen összefüggés állhat fenn közöttük.

\section{Korábbi kutatások eredményei}

Számos korábbi kutatás vizsgálta, hogy milyen tényezők befolyásolhatják a különélő szülő és gyermeke közötti kapcsolatot. Amerikában már az 1990-es évek elején elkezdték vizsgálni a témát, reflektálva a 20. század második felére jellemző magas válási arányszámokra (például Seltzer 1991; Amato-Gilbreth 1999). Az észak- és nyugat-európai országokban azonban csak a 2000-es évektől kezdték el intenzívebben vizsgálni a különélő szülők és gyermekeik közötti kapcsolattartást. Norvégiában Skevik (2006) figyelt fel arra az ellentmondásra, hogy az apák egyre aktívabb szerepet vállalnak a gyermekek életében, miközben a válási arányszámok is magasabbak, azaz sok apa nem él együtt a biológiai gyermekével. Így a különélő apák és gyermekeik kapcsolattartása egyre inkább a fókuszba került. A kutatások főként arra a kérdésre keresik a választ, hogy milyen tényezők befolyásolhatják a különélő apák kapcsolattartását gyermekeikkel (Cheadle et al. 2010; Meggiolaro-Ongaro 2015; Goldberg- Carlson 2015; Seltzer 1991), a tartásdíjfizetést (Goldberg 2015), illetve a szülői felügyeleti jog gyakorlását (Arditti-Keith 1993; Goldberg 2015).

Bár sokan feltételezik azt, hogy a válást követő időszakban jelentősen csökkenhet a különélő szülők szerepe a gyermekek életében, a longitudinális vizsgálat eredményei ezt nem támasztják alá (Cheadle-Amato-King 2010). Cheadle és szerzőtársai (2010) egy amerikai panelmintán, ahol 14 éven keresztül (1986-2002 között) követték végig a különélő apák és gyermekeik kapcsolatát, azt találták, hogy az apáknak mindössze 23\%-ánál fedezhető fel a csökkenő kapcsolattartási mintázat, ellenben az apák kétharmadánál a kapcsolattartásban nem fedezhető fel különbség, és $8 \%$-uknál a válást követő időszakban még növekedett is a kapcsolattartás mértéke. 
A 20. század második felében elkezdtek viszonylag egyértelmú egyéni és társadalmi elvárások kialakulni azzal kapcsolatban, hogy az apák minél nagyobb részt vállaljanak a gyermekek életében mind instrumentális, mind emocionális szempontból. Dermott (2003) kutatása során azt találta, hogy a korábbi generációkhoz képest az „új apák” egyre inkább olyan szülői ideált próbálnak megvalósítani, ahol érzelmileg is szoros kapcsolatot alakítanak ki a gyermekeikkel. Ugyanezt találta Takács Judit 2005 és 2008 között 55 magyar apával készített interjús vizsgálatában is, vagyis, hogy az apák megpróbálnak azonosulni ezzel a külső elvárással, azaz ők maguk is aktívan törődő apává válnak a hatására (2017; 2019). Eközben Lindberg és szerzőtársai (2017) arra hívják fel a figyelmet, hogy az együtt élő apákkal ellentétben a különélő apákkal kapcsolatos elvárások kevésbé kristályosodtak ki. Így a különélő apák esetében a társadalmi elvárásoknál és normáknál sokkal fontosabb lehet az, hogy ők milyen szerepet konstruálnak maguknak az apaság tekintetében.

Az eddigi kutatások mindenesetre feltárták, hogy a szülők szociodemográfiai hátterével, az új partnerkapcsolatok kialakításával, valamint a gyermekek nemével és életkorával kapcsolatos változócsoportoknak kulcsszerepe lehet a különélő apák és gyermekeik kapcsolattartásában, az apák tartásdíjfizetési hajlandóságában és szülői felügyeleti joguk gyakorlásában.

\section{A szülők szociodemográfiai hátterének szerepe}

A korábbi kutatások rávilágítottak arra, hogy a különélő apák szociodemográfiai háttere - mint például a jövedelmi helyzete, iskolai végzettsége és életkora - is kapcsolatban állhat azzal, hogy milyen gyakran találkoznak a velük nem egy háztartásban élő gyermekeikkel (például (Goldberg-Carlson 2015; Skevik 2006). A kedvezőbb anyagi helyzetű apák előnyösebb helyzetben lehetnek a különélő gyermekkel történő kapcsolattartás tekintetében, hiszen a kapcsolattartás sokszor anyagi ráfordítást igényel. Például ha különböző településen él az apa a gyermekétől, akkor utazási költségek merülhetnek fel, amelyek az apát terhelhetik. A korábbi kutatások azt találták, hogy minél messzebb él az apa a gyermekétől annál ritkábban látogatja (Manning et al. 2003; Cheadle et al. 2010). A jobb anyagi helyzet kapcsolatban áll a tartásdíjfizetéssel is: a magasabb jövedelmű és jobb munkaerőpiaci helyzetû apák inkább fizetik rendszeresen a tartásdíjat, mint a rosszabb anyagi helyzetú társaik (Natalier-Hewitt 2010; Cheadle et al. 2010).

Nemzetközi kutatások pozitív összefüggést találtak a különélő apák rendszeres gyermektartásdíj-fizetése és a gyermekkel való kapcsolattartás között, habár ennek iránya nem egyértelmú. Vannak olyan kutatások, amelyek azt feltételezik, hogy a gyermekükkel rendszeresen kapcsolatot tartó apák azért hajlamosabbak a megbeszéltek szerint fizetni a tartásdíjat, mert a kapcsolat révén tisztában vannak azzal, hogy a gyermekeknek milyen gazdasági igényeik vannak (Amato et al. 2009; Goldberg 2015). Ezzel szemben a rendszeres kapcsolatot nem tartó különélő apáknak kevésbé van pontos képük a gyermekneveléssel kapcsolatban felmerülő költségekről. 
Ugyanakkor van olyan kutatás, amely szerint a kapcsolat éppen hogy fordított: gyermektartásdíjat fizetnek, ezért az apák úgy érzik, joguk van ahhoz, hogy kapcsolatot tartsanak gyermekeikkel (Cheadle et al. 2010).

A kedvezőbb anyagi helyzet mellett az iskolai végzettség is fontos szerepet játszhat abban, hogy a különélő apák miként vesznek részt gyermekeik életében. A korábbi kutatások az iskolai végzettséggel kapcsolatban azt találták, hogy a magas iskolai végzettség pozitív kapcsolatban áll a láthatóság gyakoriságával és a tartásdíjfizetési hajlandósággal is (Goldberg-Clarson 2015; Manning et al. 2003). Ennek egyik lehetséges magyarázata, hogy az alacsonyabb iskolázottságú apák nagyobb mértékben azonosulnak a tradicionális apamodellel, miszerint az apák elsődleges szerepe a családban a pénzkeresés (Crompton-Lyonette 2005), így azokban az esetekben, amikor ezt a pozíciót nem tudják betölteni, sokszor tarthatják haszontalannak a kapcsolat ápolását gyermekeikkel (Goldberg 2015). Ezzel ellentétben a magas iskolai végzettséggel rendelkező apák komplexebbnek, sokszínúbbnek érzik apai identitásukat, így az anyagi háttér biztosítása mellett más területeken is igyekeznek részt venni gyermekeik életében (Goldberg 2015; Spéder 2011).

Egy másik lehetséges magyarázat szerint a magasabb iskolai végzettségű személyek nagyobb hajlandóságot és igényt mutatnak arra, hogy megfeleljenek a domináns elvárásoknak, így a tartásdíjizetését is kevesebbszer tagadják meg (Patrick et al. 1996). Több kutatás rávilágított arra, hogy azok az apák, akik gyakrabban tartják a kapcsolatot a gyermekeikkel, általában a gyermeknevelés más feladataiból is kiveszik a részüket, például az anyagi biztonság megteremtéséhez is nagyobb mértékben járulnak hozzá és a szülői döntéshozásban is nagyobb részt vállalnak (Seltzer 1991; Goldberg 2015).

Ráadásul a magasabb iskolai végzettségű szülők körében elterjedtebb, hogy a váltott gyermekfelügyelet intézményét választják (Donnelly-inkelhor 1993; Nielsen 2011), mint az alacsonyabb iskolai végzettségú társaiknál. Ennek egyik oka, hogy ők általában jobban informáltak a szülői felügyeleti jogokkal kapcsolatban, ezért közülük többen ismerhetik a váltott gyermekfelügyelet lehetőségét (Nielsen 2011). Egy másik lehetséges magyarázat, hogy több ismerettel rendelkezhetnek arról is, milyen előnyökkel járhat a gyermekek számára, ha mindkét szülőjükkel szoros kapcsolatot ápolnak és váltott nevelésben részesülnek (Bauserman 2002; Nielsen 2011). Továbbá a magasabb jövedelmú családok könnyebben fenn tudnak tartani két olyan háztartást, ahol a gyermekek otthonosan érezhetik magukat - például van külön szobájuk, saját bútoraik, ruházatuk és játékaik stb. -, mint az alacsonyabb iskolai végzettségű társaik (Donnelly-Finkelhor 1993).

$\mathrm{Az}$ apa életkora is fontos tényező lehet a kvantitatív kutatások szerint: a fiatalabb különélő apák - különösen a tinédzser korúak vagy a 20-as éveik elején járók - kevésbé vesznek részt a gyermekeik életében, mint idősebb szülőtársaik (Goldberg-Clarson 2015). Ennek hátterében az is állhat, hogy ilyen fiatal korban gyakrabban lehetett kevésbé tervezett a gyermekvállalás (Barber-Evans 2006). Lindberg és szerzőtársai (2017) 2002 és 2010 közötti amerikai adatokon kimutatták, hogy 
szoros összefüggés van aközött, hogy tervezett vagy nem tervezett volt a gyermekvállalás, és hogy a különélő apák milyen gyakorisággal tartják a kapcsolatot velük. Lindberg és szerzőtársai (2017) kutatásukban arra a megállapításra jutottak, hogy a nem tervezett gyermekek esetében szignifikánsan alacsonyabb volt a kapcsolattartás mértéke.

\section{A szülók interperszonális kapcsolatai}

A különélő apák gyermekeikkel való kapcsolattartását, tartásdijfizetési hajlandóságát és a szülői felügyeleti jog gyakorlását jelentősen befolyásolja a korábbi kapcsolat jellege és a válást követően a szülőpárok közötti viszony alakulása, illetve egy új párkapcsolat kialakítása is (Goldberg-Carlson 2015). A korábbi kapcsolat jellege azért lehet fontos, mert a házasság általában nagyobb fokú elköteleződést jelent, és a szülők valószínúleg szorosabban együttmúködtek a párkapcsolat felbomlása előtt, mint azok, akik élettársi kapcsolatban vagy esetleg LAT kapcsolatban éltek a gyermekvállalásakor (Goldberg-Carlson 2015).

Közvetlenül a válást követő időszakban a szülők általában ellenségesebbek egymással, de a konfliktusos viszony a felek között egy-két éven belül javulni szokott (Bonach 2005; Visser et al. 2017). Szintén fontos a volt párok viszonyában az, hogy elégedettek-e a gyermekfelügyelet rendezésével és a tartásdíj mértékével. Amennyiben mindkét fél elégedett, a szülők inkább képesek partneri viszonyt kialakítani a gyermeknevelés tekintetében, mint abban az esetben, ha valamelyik fél elégedetlen (Bonach 2005). Visser és szerzőtársai (2017) a társas kapcsolatok szerepét hangsúlyozzák, amennyiben a szülők kapcsolati hálója elítéli a konfliktusos viszonyt, akkor az expartnerek hajlamosabbak megbocsátani és harmonikusabb partneri viszonyt kialakítani egymással.

Murinkó és Szalma (2016) a Generation \& Gender Survey (ennek az adatbázisnak az Életünk fordulópontjai a magyar megfelelője) adatain vizsgálta, hogy a férfiak az első tartós párkapcsolat felbomlása után miként alakítanak ki új párkapcsolatot, és az előző kapcsolatból származó gyermek hogyan befolyásolja az új párkapcsolat kialakítását. Azt találták, hogy az új partnerkapcsolat létrehozásával versengő szerepek alakulnak ki a különélő apákban. Több kutatás is kimutatta, hogy az újraházasodás, illetve az új partnerrel való összeköltözés is összefüggésben áll a kapcsolattartás mértékének csökkenésével (Meggiolaro-Ongaro 2014; Gibson-Davis 2008). $\mathrm{Az}$ új kapcsolat gyakran jelenthet új elköteleződést és több időbeli ráfordítást az apa számára a gyermekével való kapcsolattartás rovására.

Amennyiben az új partnernek az előző kapcsolatából gyermeke származik, az még összetettebb családi formát eredményezhet - különösen abban az esetben, ha az a gyermek és a különélő apa is egy háztartásban élnek. Ebben az esetben nemcsak az új partnerrel való időtöltés, hanem a háztartásban élő gyermekre fordított idő is akadályozhatja a különélő apa és a gyermeke közötti kapcsolatot. Emellett az új partnerkapcsolat sok esetben járhat közös gyermek vállalásával is (Murinkó-Szalma 2015). Az új kapcsolatból származó gyermekek nevelése csökkentheti az apák 
részvételét a velük nem egy háztartásban élő gyermekeik életében is, mivel a különélő apa szívesebben invesztálhatja idejét, energiáját és gazdasági javait az új családjába, mint kudarcba fulladt párkapcsolatából származó gyermekeibe.

\section{A gyermek szociodemográfiai hátterének hatása a kapcsolattartásra}

Több kutatás jutott arra a megállapításra, hogy a különélő szülők - általában apák - esetében a gyermek életkora szignifikánsan befolyásolja a kapcsolattartás menynyiségét (Seltzer 1991; Lindberg et al. 2017). Ez a jelenség azzal magyarázható, hogy az apák általában egyszerúbben találják meg a közös hangot az idősebb gyerekekkel. Egy másik kutatás a gyermek nemével kapcsolatban fedezett fel számottevő különbséget, miszerint a házasságban élő pároknál az apák általában nagyobb hangsúlyt fektetnek jó kapcsolat kialakítására fiúgyermekeikkel (Parke 1996). Moyal (1992) különélő szülők esetében is megfigyelte, hogy az apák nagyobb valószínűséggel látogatják rendszeresen a fiúgyermeküket. A jelenség egy lehetséges magyarázata, hogy a fiúkkal több sztereotipikusan férfias közös „apa-fiú” programot tudnak szervezni, például különböző sportesemények látogatását, mint a lánygyermekekkel.

\section{A szülői felügyeleti jog, a kapcsolattartás és a tartásdíj ma- gyarországi szabályozása}

A szülői felügyeleti jogokat korábban a Családjogi törvény szabályozta - 1952 és 2013 között, azaz a családjogot a magyar jogrendszer önálló ágának tekintette (Weiss 2010). Majd a 2013-ban elfogadott és 2014-ben hatályba lépett az új polgári törvénykönyv (Ptk.) a korábbi szabályozáshoz képest koncepcionális változást hozott, mivel beemelte rendszerébe a családjogot, önálló könyvet adva a jogterületnek. Amíg a Családjogi törvény gyermekelhelyezésről beszélt, azaz akinél a bíróság a gyermeket elhelyezte, vagy akinél a szülők megállapodása alapján elhelyezték, az a szülői felügyeleti jog teljes körű gyakorlója lett (Dénesné 2017), miközben a másik szülő felügyeleti joga szünetelt. 2014-tôl azonban az új Ptk. rendelkezik a szülői felügyeleti jogok szabályozásáról, és a gyermekelhelyezés kifejezést csak akkor használja, amikor a bíróság - a szülőkön kívüli - harmadik személynél helyezi el a gyermeket. A bíróságnak ezentúl nem kell döntést hoznia arról, hogy kinél helyezzék el a kiskorú gyermeket, csak azt kell meghatároznia, hogy ki gyakorolja elsődlegesen a szülői felügyeleti jogokat, így egyik fél sincs kiszorítva a szülői felügyelet gyakorlásából.

A szülőknek különösen a gyermek sorsát érintő lényeges kérdésekben kell együttmúködniük. Ilyen lényeges kérdésnek számít a „kiskorú gyermek neve meghatározásának, gondozásának, nevelésének, tartózkodási helye meghatározásának, vagyona kezelésének, törvényes képviseletének joga és kötelessége, a gyámnevezésnek és a gyámságból való kizárásnak a joga”3. Kevesebb szó esik arról, hogy a szülői felügyelet nemcsak

3 Ptk. 4:175§ (2) [Közösen gyakorolt szülöi felügyeleti jogok]. 
jogokat, hanem kötelességeket is tartalmaz, azaz a különélő szülőnek is kötelessége, hogy részt vegyen a gyermek sorsát meghatározó döntésekben. Továbbá a gyermekkel együtt élő szülőnek a "gyermek fejlődésérôl, egészségi állapotáról, tanulmányairól a különélő szülöt megfelelő időközönként tájékoztatnia kell, és a különélő szülö érdeklődése esetén a gyermekkel kapcsolatos felvilágosítást meg kell adnia".

A kapcsolttartást is az új Ptk. szülői felügyeleti jogával foglalkozó fejezet tárgyalja. A szülőknek lehetőségük van arra, hogy közös megegyezést hozzanak arról, hogy a különélő szülő milyen gyakorisággal és milyen időtartamban találkozzon gyermekével. Ha ebben a szülők nem tudnak egyezségre jutni, akkor a kapcsolattartásról - kérelemre vagy a gyermek érdekében hivatalból - a bíróság dönt. A szülői felügyeleti joghoz hasonlóan a különélő szülőnek nemcsak joga a gyermekével kapcsolatot tartani, hanem kötelessége is. ${ }^{5}$

A tartásdíjat szintén az új Ptk. 4. könyve szabályozza egy külön fejezetben. A kiskorú gyermek tartására a magyar jogrendben speciális szabályok vonatkoznak, azonban irányadónak számítanak a rokontartás általános szabályozásai is. Kiskorú gyermek esetében annak életkorából kifolyólag adódik, hogy a létfenntartáshoz szükséges anyagiakkal nem rendelkezik, így a kiskorú gyermek tartásdíjra szorulása vélelmezett (Joggyakorlat Elemző Csoport 2018). A gyerektartás mindkét szülőnek feladata - míg a gyermektôl különélő szülő anyagilag, a gyermekkel egy háztartásban élő szülő természetben köteles támogatnia gyermekét. A korábbi Családjogi törvényi szabályozása szerint a tartásdij mértéke százalékban volt meghatározva, mégpedig egy gyermek után a különélő szülőnek a jövedelme mintegy 15-25\%-át kellett megfizetnie. Ez annyiban módosult, hogy bár ez az arány irányadó maradt, már nem százalékban mérve, hanem konkrét összegben határozzák meg. Az öszszeg meghatározásakor továbbra is a szülők döntése a mérvadó. Elviekben lehetőség van arra, hogy a bíróság külön intézkedés nélkül elrendelje, hogy az összeg minden évben a fogyasztói árindex mértéke szerint növekedjen, azonban a Joggyakorlat Elemző Csoport $^{6}$ (2018) az elkészített jelentésében felhívta a figyelmet arra, hogy a törvény szövege pontatlan, mivel nem derül ki, hogy a KSH által közzétett kétféle éves fogyasztói árindex közül melyiket kell alkalmazni. Ennek következtében a bíróság gyakran nem rendelte el, hogy a valorizációt automatikusan figyelembe vegyék a jogerős ítéletben, amit az is bizonyít, hogy a Joggyakorlat Elemző Csoport (2018) által vizsgált 250 tartásdíjra vonatkozó jogerős ítéletből mindössze 9 tartalmazza a valorizáció figyelembevételét. További újdonság, hogy lehetőség nyílik arra is, hogy a tartásdíjat egy pénzösszeg vagy vagyontárgy egyszeri juttatásával rendezze a tartásdíjra kötelezett. Ebben az esetben megkerülhető a későbbi valorizáció problémája.

4 Ptk. 4:174. [A gyermekkel együtt élő szülő tájékoztatási kötelezettsége].

5 Ptk. 4: 178 (2) [A kapcsolattartás joga].

6 A bírósági joggyakorlat-elemző csoport feladata a bíróságok szervezetéről és igazgatásáról szóló törvény értelmében az ítélkezési gyakorlat vizsgálata, bírósági döntések elemzése. A vizsgálati tárgyköröket a Kúria elnöke határozza meg évente. A joggyakorlat-elemző csoport a vizsgálat eredményéről összefoglaló véleményt készít, amely a Kúria honlapján is olvasható. 
A Joggyakorlat Elemző Csoport (2018) arra is rávilágított, hogy rendkívül nagy területi egyenlőtlenségek figyelhetők meg a tartásdíj mértékének megállapításakor. A vizsgálatba bevont esetek alapján például van olyan törvényszék, ahol a minimum- és a maximumtartásdíj 15000 Ft és 30000 Ft között változik (Nyíregyházi Törvényszék), míg a Fővárosi Törvényszék esetében a szórás ennél jelentősen nagyobb: a minimum összeg 8000 Ft és a maximum összeg 180000 Ft volt. Ezenkívül arra is rávilágítottak, hogy a láthatatlan jövedelem kérdése sem egyformán releváns minden térségben. Például a fővárosban és a környező régióban zajló tartási perek hosszadalmas bizonyítással és nagyobb pertartartammal járnak, mivel gyakrabban merül fel a láthatatlan jövedelmek kérdése, mint az gazdaságilag elmaradottabb régiókban (Joggyakorlat Elemző Csoport 2018).

\section{A minta és a módszerek bemutatása}

Kutatásunk empirikus alapját 2019 április és június között készített 17 olyan eset adta, ahol az egyik fél - általában az apa - nem él együtt legalább egy 18 év alatti gyermekével. 14 esetben az anyával éltek a gyermekek, 2 esetben váltott gyermekfelügyeletre került sor, 1 esetben pedig az apa élt együtt a gyermekeivel és az anya nem élt együtt velük. Mivel az új polgári törvénykönyv eltérően rendelkezik a kiskorú, illetve nagykorú, de még nappali tagozatos fiatalok utáni tartásdíjfizetési kötelezettségről, ezért fontosnak tartottuk, hogy olyan szülők kerüljenek a mintánkba, akik ennek fizetésére a gyermek kiskorúsága miatt a körülményektől függetlenül kötelesek.

Összesen 17 esetet vizsgáltunk, melynek során 25 félig strukturált interjút készítettünk 8 szülőpár mindkét tagjával, amikor mind az anya, mind az apa részt vett a vizsgálatban. A diádikus interjúk előnye pedig az, hogy rávilágíthatunk azokra a kérdésekre, melyeket az anyák és az apák különbözően látnak. Emellett 5 apával és 4 anyával készítettünk interjút. A 4 anya egyszülős családfőként funkcionál, azaz nem élnek párkapcsolatban, egyedül élnek a kiskorú gyermekeikkel. Az 5 apa közül négy különélő apának tekinthető, egy pedig váltott gyermekfelügyeletben neveli a gyermekét a volt párjával. A 4 különélő apa közül 3 apa alakított ki új párkapcsolatot, és egyiküknek vele élő gyermeke is lett az új párkapcsolatából. Azért döntöttünk úgy, hogy olyan eseteket is bevonunk a vizsgálatunkba, amikor a szülőpár valamely tagja elutasította a felkérésünket, mert azt feltételeztük, hogy közöttük kevésbé jó a viszony, mint azon párok között, akiknél mindkét fél vállalta az interjút.

Az interjúalanyok megkeresése hólabda módszerrel történt, azaz először az ismerőseink olyan ismerőseit kerestük meg, akikre illettek az általunk előre meghatározott kritériumok, azaz legalább egy 18 év alatti gyermekük van, akivel nem élnek együtt vagy részben nem élnek együtt (amennyiben váltott gyermekfelügyeletre került sor). Törekedtünk arra, hogy a mintába különböző iskolai végzettségú és településtípuson élő, illetve különböző életkorú gyermeket nevelő szülők kerüljenek. Az 1. táblázat részletesen ismerteti a résztvevők szociodemográfiai hátterét. 
A mintába kerülő alanyokkal előzetesen ismertettük a kutatás célját és annak releváns részleteit, illetve biztosítottuk a résztvevőket az anonimitásról és egyéb jogaikról (például, hogy bármikor megszakíthatják a részvételt - erre egyébként egy esetben sem került sor). Minden interjúalanytól kértünk beegyezési nyilatkozatot, amelyben tisztáztuk, hogy miként kezeljük az adatokat, és biztosítottuk őket, hogy azokat csak kutatási célra használjuk fel. Minden interjúalanynak álnevet adtunk, ügyelve arra, hogy az expároknak azonos betűvel kezdődő nevet válasszunk az elemzés áttekinthetősége érdekében.

1. táblázat: A minta szociodemográfiai áttekintése

\begin{tabular}{|c|c|c|c|c|c|}
\hline Név & Életkor & $\begin{array}{c}\text { Vele élő } \\
\text { gyermekek } \\
\text { száma }\end{array}$ & $\begin{array}{c}\text { Különélő } \\
\text { gyermekek } \\
\text { száma* }\end{array}$ & Településtípus & $\begin{array}{c}\text { Iskolai } \\
\text { végzettség }\end{array}$ \\
\hline Alex & 43 & 0 & 2 & Főváros & Magas \\
\hline Alexandra & 40 & 2 & 0 & Főváros & Magas \\
\hline Barnabás & 45 & 0 & 2 & Város & Magas \\
\hline Barbara & 45 & 2 & 0 & Város & Magas \\
\hline Csongor & 41 & $\begin{array}{c}1 \text { (váltott } \\
\text { elhelyezés) }\end{array}$ & $\begin{array}{c}1 \text { (váltott } \\
\text { elhelyezés) }\end{array}$ & Főváros & Magas \\
\hline Csenge & 40 & $\begin{array}{c}1 \text { (váltott } \\
\text { elhelyezés) }\end{array}$ & $\begin{array}{c}1 \text { (váltott } \\
\text { elhelyezés) }\end{array}$ & Főváros & Magas \\
\hline Dániel & 40 & 2 & 1 & Város & Közepes \\
\hline Daniella & 38 & 1 & 0 & Város & Közepes \\
\hline Erik & 37 & 1 & 1 & Falu & Magas \\
\hline Erika & 29 & 1 & 0 & Falu & Közepes \\
\hline Kornél & 50 & 0 & 4 & Főváros & Magas \\
\hline Karol & 45 & 4 & 0 & Város & Magas \\
\hline Péter & 48 & 2 & 0 & Város & Közepes \\
\hline Petra & 48 & 0 & 2 & Külföld & Közepes \\
\hline Tamás & 48 & 0 & 1 & Város & Közepes \\
\hline Tamara & 46 & 1 & 0 & Város & Magas \\
\hline Fülöp & 43 & 0 & 5 & Város & Magas \\
\hline Géza & 48 & 0 & 3 & Falu & Alacsony \\
\hline István & 45 & 1 & 2 & Főváros & Magas \\
\hline Márk & 47 & $\begin{array}{c}2 \text { (váltott } \\
\text { elhelyezés) }\end{array}$ & 0 & Fóváros & Magas \\
\hline Szabolcs & 37 & 0 & 1 & falu & Alacsony \\
\hline Ágnes & 52 & 1 & 0 & Falu & Alacsony \\
\hline Niki & 36 & 1 & 0 & Főváros & Magas \\
\hline Nóra & 31 & 3 & 0 & Város & Magas \\
\hline Rita & 45 & 2 & 0 & Város & Alacsony \\
\hline
\end{tabular}

*A különélő gyermekek számánál nem vettük figyelembe azokat a nagykorú gyerekeket, akik szüleiktől külön költöztek és nappali tagozatos felsőoktatásban sem vesznek részt.

A magas iskolai végzettségú alanyok felülreprezentáltak voltak - 16 diplomával rendelkező interjúalany került a mintába, ami egyrészt annak köszönhető, hogy őket könnyebb volt elérni, másrészt pedig a magas iskolai végzettségűeket nagyobb részvételi hajlandóság jellemezte, mint alacsonyabban iskolázott társaikat. Többször előfordult, hogy az alacsony iskolai végzettségű szülők elutasították a felkérést, 
például arra hivatkozva, hogy ők maguk nem tartják a kapcsolatot a különélő gyermekkel vagy nem látják értelmét egy ilyen jellegú kutatásnak. Településtípus szerint jobban megoszlott a mintánk: 8-an a fővárosban, 12-en nagyobb városokban, 4-en községekben, egy interjúalanyunk pedig külföldön élt. A legtöbb apának egy vagy két különélő gyermeke volt, három apának volt ennél több különélő gyermeke. Két esetben történt váltott gyermekfelügyelet, és egy olyan eset is volt, ahol az elsődleges gyermekfelügyeleti jog az apát illette meg (az anya külföldön élt).

Az interjúk átlagosan 40-50 percig tartottak, és a szülőpárokkal minden esetben külön-külön készítettük azokat. Az interjúvázlatunkban témaköröket határoztunk meg és nyitott kérdéseket fogalmaztunk meg. Az interjú a következő nagyobb egységekre tagolódott: (1) a gyerekkori családból hozott tapasztalatok, (2) karriertörténet, (3) párkapcsolat-történet és gyermekvállalás, (4) a kapcsolattartás a különélő gyermekkel, a szülői felügyeleti jog gyakorlása és a tartásdíj fizetésének kérdése.

Az interjúkról készült hangfelvételt legépeltük, és Nvivo szoftver segítségével tematikus elemzést végeztünk. Ezenfelül a szövegekből két strukturális kódkönyvet készítettünk, melyeket ellenőrzés céljából összevetettünk egymással, és eltérés esetén megvitattuk ennek lehetséges okait. A következő kódcsoportokat állítottuk fel (zárójelben, hogy hány esetben fordult elő a 17 esetből): bíróság/hatóság bevonása (16), tartásdíj összege (16), gyermekfelügyelet/elhelyezés (15), elégedettség a tartásdíjjal (7), rugalmasság/változtatás a kapcsolattartásban (11), fizetés elmaradása (11), pluszköltségek (15), láthatóság/kapcsolattartás/találkozás (15), új párkapcsolat (5).

\section{Eredmények}

\section{A szülői felügyeleti jog gyakorlásának kérdése}

A 17 eset közül a mintánkban 2 esetben fordult elő a közös gyermekfelügyelet, 1 esetben kizárólag az apa neveli a gyermekeket, és legtöbbször (14 esetben) kizárólag az anya látja el a gyermekfelügyeletet. Az interjúalanyok többségénél fel sem merült, hogy az apa legyen a szülői felügyeleti jog teljes körű gyakorlója, sem a váltott gyermekfelügyelet lehetősége. Ebből a szempontból kivételnek számított a fővárosban élő, magas iskolai végzettségú István, aki, miután a felesége kezdeményezte a válást, a bíróságon kérte, hogy a gyermekek felügyeleti jogát ő gyakorolhassa. Bár István ideálisnak találta volna a váltott gyermekfelügyeletet, erre viszont csak akkor kerülhet sor, ha mindkét fél kérelmezi azt. Az István és expárja között elmérgesedett viszony miatt erre a volt felesége nem volt hajlandó, ezért döntött István amellett, hogy akkor kizárólagos felügyeletet kér. Azonban a bíróság ezt a kérelmét elutasította, „arra hivatkoztak, hogy a gyerekek eddig is az anyával voltak”, annak ellenére, hogy a külön költözést követő időszakban István napi szinten visszajárt a közös lakásukba azért, hogy továbbra is gondozhassa a kisgyermekeit.

A szülői felügyeleti jog teljes körű gyakorlásának kérelme más apák esetében nem merült fel, azonban a váltott gyermekfelügyeleti jog gyakorlását több család is fonto- 
lóra vette. A szintén magas iskolai végzettségű, kisvárosban élő Barnabás 2004-ben vált el, amikor még a jogi keretek nem is tették lehetővé a közös szülői felügyeleti jog gyakorlását, hiszen erre a 2014-ben hatályba lépett új polgári törvénykönyv adott először lehetőséget. Így az ő esetükben is az anyával maradtak a gyermekek, amit akkoriban Barnabás is támogatott. Azonban ezt már nem látja ideálisnak, és a mai társadalmi normák és jogi keretek között más döntést hozna. A következőképpen fogalmaz: „én a váltott nevelésben hiszek, csak abban az időben ez még nem volt se divat, sem én nem voltam rá felkészülve. Most viszont látok párokat, hogy egy hét itt, egy hét ott, és én ezt tartom a legjobb modellnek, mert így az apa-és az anyakép is rendben van, részt vesznek mindketten kellőképp a gyerek életében, és benne vannak a döntéshozatalban”. A 2013 után elvált családok esetében tényleges szemponttá kezd válni, hogy mindkét fél egyenlően részt vegyen a gyermekek életében. Ezt bizonyítja, hogy a KSH 2017es adatai alapján a felbontott, érvénytelenített házasságokban a kiskorú gyermekek több mint 13\%-át az anya és az apa váltott gyermekfelügyeletben neveli (KSH 2019).

Interjúalanyaink közül is két fővárosi, magas iskolai végzettségú család választotta ezt a lehetőséget. Márkéknál megfigyelhető volt, hogy ő már a kezdetektől fogva nagyon intenzíven részt vett a gyermekek gondozásában. Ez a szoros apagyermek kapcsolat később a szülői felügyeleti jog rendezésénél is szerepet kapott, mivel tinédzser fiai kifejezetten azt akarták, hogy „3 napot velem vannak, 4-et vele [az anyával]". Ezzel ellentétben Csongor a gyermek gondozását eleinte a feleségére hárította, és a felesége volt az, aki fokozatosan vonta bele Csongort a gyermekgondozási feladatok ellátásba, amikor szétköltöztek. Csongor volt felesége, a szintén magas iskolai végzettségű, fővárosban élő Csenge egy egész stratégiát épített fel arra, hogy miként vonja be Csongort a gyermekgondozási feladatok elvégzésébe a szétköltözés idején: „Kitaláltam egy menetrendet, hogy az első három hónapban el kell érni, hogy 48 órát egyhuzamban az apjánál töltsön. Ezt hónapokkal elötte el is küldtem neki [Csongornak]”. Végül is azért került sor a váltott gyermekelhelyezésre (egy hetet Csengénél, egy hetet Csongornál), mert Csenge úgy találta, hogy ez szolgálja legjobban a gyermek érdekét. Csongor részéről pedig azért volt vonzó alternatíva a váltott gyermekelhelyezés, mert így elkerülhető volt számára a tartásdíj megfizetése. Ő ugyanis semmiképpen sem szeretett volna azért tartásdijat fizetni, hogy azt a volt felesége bébiszitterekre költse. A fenti minták ellenére azonban a magas iskolai végzettségú apák többségénél is megfigyelhető volt az a tradicionális szemlélet, hogy jobb, ha az anya gyakorolja a szülői felügyeleti jogot a kapcsolat felbomlásakor. Például a főiskolai végzettségű, falun élő Erik a gyermekfelügyelet kérdésénél úgy fogalmazott, hogy „nem akartam én elvenni az anyjától”. Az általa választott szóhasználat is tisztán mutatja, hogy ő úgy véli, a gyermek elsősorban az anyához tartozik.

$\mathrm{Az}$ alacsonyabb iskolai végzettségű férfiak körében pedig elterjedt volt az a nézet, hogy a gyermeknek is jobb az, ha az anyjával marad. Az érettségivel rendelkező, városban élő Tamás szintén úgy véli, hogy a gyermeknevelés szorosabban kötődik a női szerepekhez, ezért számára „nem volt kérdés”, hogy a gyermeke az anyánál ma- 
rad, mivel „egy gyermeknek az édesanyja tudja a legtöbb segítséget és az érzelmet nyújtani kiskorában”. A szintén városban élő, érettségivel rendelkező Péter szerint ráadásul a magyar jogrendszer is annak kedvez, hogy az anyánál maradjanak a kiskorú gyermekek: „Tudtam, hogy a magyar törvények azt mondják, hogy az anyánál. Ó ragaszkodott, mint anyatigris, hogy nála maradjanak a gyerekek, és ezért nem is erôltettem ezt a dolgot”. Érdekes, hogy ennek ellenére később mégis ő lett a szülői felügyeleti jog elsődleges gyakorlója, habár erre nem egy közös döntés meghozatala alapján került sor, hanem mert az anya külföldön vállalt munkát. Erre Péter így emlékszik vissza: „Közölte, hogy vagy nálam lesznek a srácok, vagy elviszi őket az anyukájához, és ő vigyáz rájuk. Mondtam, hogy az én gyerekeimet anyukád nem fogja nevelni, és akkor így maradtak nálam a srácok. Nem volt egyszerü." Péter példája rámutat arra, hogy sokszor külső tényező kell ahhoz, hogy az apához kerüljenek a gyerekek.

Az a mintázat, hogy a gyermek elsősorban az anyához tartozik és a férfiak csak másodrangúak a gondozási és érzelmi feladatok ellátásában, többször felmerül az interjúk során. Érdekes, hogy ezzel a szemlélettel azonosul a gyermekét váltott szülői felügyeleti gyakorlatban nevelő Csongor is, aki az interjú végén hozzáteszi, hogy kissé kényelmetlenül érzi magát, hogy nem csak az anya gyakorolja a szülői felügyeletet: „Nem tehetem meg, hogy csak apa legyek, sajnos anyának is kell lennem. Nehéz nekem az anyaszerep, fóleg ilyen rendezvényeken, amikor pl. én csinálom a haját. ... Ez azért szar érzés, ez kicsit bagatell dolog, de ez nem az én feladatom lenne. Az anya az anya, az apa meg apa". Ez az interjúrészlet rávilágít arra, hogy a nehézséget tulajdonképpen a nemi szerepek el nem különülése okozza, ami a váltott gyermekfelügyelet estén elkerülhetetlen.

A mintákban a két alacsony iskolai végzettséggel rendelkező apánál még ennél is intenzívebben jelentek meg érvként a gyermekelhelyezéssel kapcsolatban a tradicionális nemi szerepek. Amíg a korábbi példák jól szemléltetik, hogy általában az anya feladatköréhez tartozónak vélik a gyermekről való gondoskodást, addig a munkaerőpiaci részvétel általában egyenlően oszlik meg a két fél között. Ezzel szemben a két alacsony iskolai végzettségű interjúalanyunknál erősen kettéválik a kenyérkereső és a gondoskodó szerep: az anyagi javak megteremtése elsősorban a férfiak feladatává válik. Ebben a tradicionális felállásban a férfiak általában a főállásuk mellett további pluszmunkákat is vállalnak, hogy előteremtsék a család jövedelmét, így ilyen körülmények között fel sem merülhet, hogy a kisgyermek náluk maradjon. Például az alacsony iskolai végzettségű, falun élő Géza beszámolt arról, hogy a volt felesége közvetlenül a kapcsolat felbomlását követően depresszióval küzdött, és ennek következtében gyógyszerekkel túladagolta magát. Géza úgy látja, hogy „akkor megpróbálhattam volna elvenni a gyerekeket. De én nem, mert valakinek dolgozni is kellett”. Az alacsony iskolai végzettségű, falun élő Szabolcséknál is az a modell volt megfigyelhető, hogy a férfi a kizárólagos kenyérkereső, habár náluk Szabolcs kifejezetten ellenezte ezt a felállást. Azt mondta: „amikor a gyerek már egy kicsit nagyobb volt, kértem arra [az élettársam], hogy menjen dolgozni”. Sőt azt is hangsúlyozta, hogy 
„Én, ha még egyszer eljutnék arra a szintre, nekem olyan nő nem kéne, akit el kéne, hogy tartsak”. Ez a felállás azzal járt, hogy a folyamatos pluszmunkák vállalása miatt ő maga teljesen kiszorult a gyermekgondozásból, így a kapcsolat felbomlásakor is egyértelmű volt, hogy a gyermekfelügyelet jogát az anya gyakorolja. Az alacsony iskolai végzettségű, falun élő Ágnesnek sem volt fizetett munkája, miközben a párja kamionsofőr volt, ezért sokszor nem tartózkodott otthon. Ágnes így fogalmazott: „ő járta a saját útját, hát, most mondjam azt, hogy a szekeret egyedül húztam, egyedül neveltem a gyereket”. Így az esetükben sem volt kérdés, hogy Ágnes folytatja a gyermekről való gondoskodást a párkapcsolat felbomlása után is.

Olyan eset is előfordult, ahol intergenerációs minták mutathatók ki. Például Dániel (város, érettségi) saját, több évtizeddel ezelőtti tapasztalataiból táplálkozik. Amikor a szülei elváltak, őt a bíróság az anyjának ítélte, annak ellenére, hogy annak alkoholproblémái voltak, valamint, hogy ő maga sem nála szeretett volna élni. Édesapja reakcióját arra, hogy szívesebben maradna nála, így jellemezte: „Örült neki, de semmi”. Erős összefüggés mutatkozik a korábbi tapasztalatai és az ő saját gyermekének az elhelyezése között. Véleménye szerint „jobb neki az anyjánál”, és „... akkor és most is az van, hogy a válások nagy többségében, kb. 90\%-ban, az anyáknál maradnak a gyerekek". Mivel Dániel az expárját alkalmasabbnak találta a gyermeknevelésre, mint a saját anyját, ezért meg sem fordult a fejében, hogy ne az anyához kerüljön az akkor hároméves fia.

\section{A tartásdij fizetésének kérdése}

A gyermektartás kérdése az egyik leginkább konfliktussal terhelt terület a különélő szülők körében. Ráadásul a Joggyakorlat Elemző Csoport (2018) rámutatott arra, hogy egyre növekszik az annak megállapítására, felemelésére, leszállítására és megszüntetésre vonatkozó kérelmek száma. A legtöbb esetben bírósági határozat született a gyermek tartásdíjának megállapításáról, azonban az alacsonyabb iskolai végzettségűek esetében többször is előfordult, hogy bíróságon kívül rendezték a kérdést. Ugyanakkor a tartásdíj kérdése azért is kiemelkedően fontos Magyarországon, mert azok közül, akik 18 év alatti gyermeket nevelnek - akik korábbi párkapcsolatból származnak, azaz az apa nem ismeretlen - mindössze 57\% kap a különélő szülőtől rendszeres anyagi támogatást (Monostori 2019). Ennek ellenére az állam által megelőlegezett gyermektartási díjban részesülők aránya szintén nagyon alacsony (Monostori 2019).

\section{A tartásdíjizetés elmaradása}

A fenti statisztikák azt jelzik, hogy gyakran egyáltalán nem kerül sor tartásdíjfizetésre, vagy időszakosan elmaradhat annak fizetése. A mintánkban az előbbire példa az alacsony iskolai végzettségű, faluban élő Rita esete, aki bár nem vált el, de különköltözött férjétől és a gyermekeitől. Általában a különélő szülő fizet tartásdíjat, de Ritáék este ebből a szempontból kivételes, mert annak ellenére, hogy különköl- 
tözött, továbbra is napi szinten gondoskodott tizenéves gyerekeiről. „Én megfőztem az albérletemben, hazavittem nekik, elláttam őket, kimostam, kivasaltam, aztán mentem én vissza. Nem aludtam ott, ez volt a lényeg." Erre azért is kerülhetett sor, mert a férje hétfőtől péntekig vidéken tartózkodott a munkája miatt. Bár Rita nem lakott a gyermekeivel, továbbra is ő tekinthető a gyermekek fő gondozójának és anyagi támogatójának, így nem látta szükségét annak, hogy ő fizessen tartásdíjat. Amikor arra került sor, hogy az apa a gyerekeket is bántalmazta, ők is Ritához költöztek az albérletbe. Ekkor sem került sor arra, hogy az apa tartásdíjat fizessen, arra hivatkozva, hogy Rita döntése volt, hogy elhagyja őt. Az alacsony iskolai végzettségú, vidéken élő Ágnes nem is igényelt tartásdíjat volt párjától, amikor elköltözött tőle, annak ellenére sem, hogy nagyon szegény körülmények között (se víz, sem áram, sem fütés nem volt a lakásban) élt a lányával. Végül a családsegítők unszolására igényelte meg a tartásdíjat az elköltözés után egy évvel, addig anyagilag is egyedül gondoskodott lányáról.

A városban élő közepes iskolai végzettségű Péteréknél először jogi úton történt a megegyezés, miszerint Petránál maradtak a gyerekek és az apa meghatározott öszszegű tartásdíjat fizetett. Amikor Petra külföldön vállalt munkát és a gyermekek Péterhez költöztek, kezdetben Petra átvette a tartásdíjfizetési kötelezettséget Pétertől, ám ez rövid időn belül elmaradt. Péter ezzel kapcsolatban így fogalmazott: „ha öbenne nincs meg sajnos ez a meglátás, hogy kéne, akkor elengedem”. Mivel Péter úgy látta, hogy meg tudja oldani egyedül is a helyzetet, ezért inkább nem fordult bírósághoz.

A tartásdíj elmaradása nemcsak a szétköltözéskor jelentkező „kezdeti” probléma, hanem többen beszámoltak arról, hogy a meglévő folytonos fizetési gyakorlatban is elmaradás következett be. A magas iskolai végzettségú, kisvárosban élő Barbaráéknál többször is sor került rövidebb-hosszabb elmaradásokra, mivel a volt férje vállalkozása akadozott. Barbara először a gyámhivatalhoz fordult segítségért, azonban ez a megoldás nem mutatkozott hatékonynak, mivel Barbara azt a választ kapta, hogy „ha az apa azt mondja, hogy az anyagi bajai miatt nem tud [40 ezret] fizetni, csak 10 ezret, akkor a hajlandóság megvan az apa részérôl, és akkor az állam már nem úgy segít, ahogy kell”. Ennek hatására Barbara és exférje alternatív megoldásokat dolgoztak ki közösen, amivel Barbara elégedett volt: „Tehát az első tartásdij hiányát azt úgy oldottuk meg, hogyo ô segített nekem a lakásnál a felújitásban. Volt olyan is, hogy bedöglött a kocsim, és akkor adott egy használt autót, és nem kért semmit érte. Szóval azért így számíthattam rá." A szintén magas iskolai végzettségű, városban élő Nóra is többször került olyan helyzetbe, hogy átmenetileg nem került sor a tartásdíj megfizetésére. Ő a rendőrséghez fordult és feljelentést tett volt párja ellen. Végül nem született közös megoldás, és a fizetés ugyanúgy rendszertelenül érkezik, ami elég nehéz helyzetbe hozza az egyedülálló háromgyerekes anyát. 
A tartásdij mértékének kérdése

A legtöbb esetben az, aki kapja a tartásdíjat, elégedetlen annak mértékével, és a különélő szülők között is csak két olyan eset volt, ahol a tartásdíjat fizető sokallta volna az összeget. Ez részben annak is köszönhető, hogy sokszor maga a különélő szülő határozta meg, hogy mennyit tud, illetve akar fizetni. Az alacsony iskolai végzettségú, falun élő Szabolcs esetében ez teljesen önkényes volt, azaz bírósági határozat sem született annak mértékéről. Ő maga erről a következőképpen nyilatkozott: „Hát én, amit meghatároztam [annyit fizettem], úgy voltam vele, hogy érje be”. Azonban akkor is, amikor formális keretek között született meg a döntés, sokszor találkoztunk azzal, hogy az apa akarata érvényesült. Ilyen eset volt például a magas iskolai végzettségű, fővárosban élő Alexéké, akiknél történtek alkudozások a felek között, azonban Alex úgy látja, hogy az „é általam javasolt ellenösszeghez közelebbi matek jött ki”. Ugyanakkor olyan eset is volt, ahol a válás előtti szétköltözéssel egy időben, azaz jóval a bírósági határozat előtt tudatosan kezdett el saját maga által meghatározott tartásdíjat utalni a magas iskolai végzettségú Csongor. Ennek hátterében a volt felesége, Csenge szerint nyilvánvalóan az a megfontolás állt, hogy a bíróság is ezt az összeget hagyja majd jóvá. Később azonban nem került sor tartásdíjfizetésre az ő esetükben, mivel a váltott gyermekfelügyelet mellett döntöttek.

$\mathrm{Az}$ is előfordult, amikor a különélő apa tisztában volt azzal, hogy a tartásdíj mértéke valójában nem fedezi a gyerekkel járó költségek ráeső részét, de nem fizetett többet, még akkor sem, ha ez módjában állt volna. Ez volt tapasztalható a főiskolai végzettségú, falun élő Eriknél, aki havi 35 ezer forintot fizet a gyermeke után, és ő maga is azt állítja, hogy ez semmire sem elég. Mégsem növeli az összeget - annak ellenére sem, hogy anyagilag megtehetné. Ezt azzal magyarázza, hogy ezt a helyzetet [különélést] a párja idézte elő, így neki is kell megoldania a gyermek ellátását.

A tartásdíj összegének meghatározásakor az is előfordult, hogy a különélő szülő nem pénzben fizette azt. István például lemondott a családi házuk tulajdonrészéről gyermekei javára a gyermektartásdíj egyszeri megfizetéseként - ez az opciót egyébként az új Ptk. tette lehetővé. Hasonló mintázat figyelhető meg Szabolcséknál is, akik informális úton rendezik a tartásdíj fizetését. Szabolcs ugyanis egy kezdeti nagyobb összeggel támogatta volt párja különköltözését, az albérleti díj megfizetését és annak háztartási eszközökkel való felszerelését. Később önkényesen úgy határozott, hogy a tartásdíj későbbi fizetésekor ezt az összeget le kell vonni: „Mondtam neki, hogy amit segitettem, azt szépen letudhatod gyerektartásba, szépen oszd le magadnak. És amíg az le nem fogy, addig, ha fejre állsz, akkor sem kapsz."

A magas iskolai végzettségű Erikéknél a bíróság konkrét összeget határozott meg a gyermektartás rendezésére, azonban azt a két hónapot, amelyet visszamenőleg kellett fizetnie, Erik nem volt hajlandó készpénzben törleszteni. „Mondtam a bírónak, hogy nem fogom kifizetni, majd a pelenkába, a tápszerbe, ebbe-abba kifizetem... Mondom, nem fogom a kezébe adni a készpénzt." Ezt azzal indokolta, ha a tartásdíj-elmaradást pénzben fizeti ki, „azt arra költi, amire akarja”. Ez iskolapéldája a szakiroda- 
lomból jól ismert (Natalier 2010) hatalomgyakorlási mechanizmusnak, tehát azzal akarja kontroll alatt tartani az expárját, hogy elveszi tőle a neki jogosan megítélt pénz felett való szabad rendelkezés jogát. Az alacsony iskolai végzettségű Szabolcs is kontrollálja párja pénz feletti szabad rendelkezési jogát azáltal, hogy nem a volt élettársának, hanem személyesen kiskorú fiának adja oda a tartásdíjat, hogy az szabadon költse el, amire szeretné, és ne az anya döntse el, hogy mire lenne szüksége a gyermekének.

A tartásdíj összegének megállapításánál további két olyan terület van, amely éles konfliktusokat idézhet elő a felek között. Az egyik a láthatatlan jövedelmek kérdése, amire a Jogelemző Csoport (2018) is felhívta a figyelmet. Az ebből származó problémák különösen a fejlettebb régiókban (főváros és Pest megye) és a magasabb jövedelemmel rendelkezők körében fordulhatnak elő. Az interjúalanyok közül is a jobb anyagi helyzetűeknél és főként a vállalkozóként dolgozóknál találtunk példát a láthatatlan jövedelem problémájára. Feltehetôen ez azzal is kapcsolatban állhat, hogy a kedvezőtlenebb szociodemográfiai háttérrel rendelkezők inkább informális úton rendezik a tartásdíj kérdését, így ott a láthatatlan jövedelem ezért is kevésbé hangsúlyos probléma, mint a kedvezőbb szociodemográfiai háttérrel rendelkező szülők esetében. A magas iskolai végzettségű Csenge és a szintén magas iskolai végzettségű, vállalkozóként dolgozó Csongor a különválás kezdetekor, amikor Csongor önkényesen döntött a tartásdíj összegéről és Csenge ezt kevesellte, azt a választ kapta, hogy „ha ez nekem kevés, akkor ö ennyit se fog adni, mert ő feketén keres”. Bár Csenge tudta, hogy jogi lépéseket is tehetne ez ellen, nem fordult ilyen eszközökhöz, így végül mediáció útján rendezték a tartásdíj összegének kérdését. Mégpedig oly módon, hogy a váltott gyermekelhelyezést választották, így senkinek sem kell tartásdíjat fizetnie.

A fővárosban élő magas iskolai végzettségű Niki volt partnere is vállalkozóként dolgozott és ő is megpróbálta eltitkolni láthatatlan jövedelmét a tartásdíj összegének meghatározásakor, azonban Niki jogi lépéseket tett annak érdekében, hogy a tényleges bevételéhez mérten fizesse meg a tartásdíjat. „Amennyit ő vállalt, én annál többet tudtam bizonyítani." Ennek hatására a bíróság bizonyítási indítványt rendelt el, amely Niki részéről sikeresen záródott, azaz a láthatatlan jövedelmek is alapul szolgáltak a tartásdíj összegének meghatározásakor.

\section{A tartásdij valorizációja és módosítása}

A másik konfliktusos terület a tartásdíj módosításának kérdése. Azt tapasztaltuk, hogy a valorizációt nemcsak a felek egymás között nem veszik figyelembe, hanem a mintánkba került összes esetben a bíróság is figyelmen kívül hagyta, hogy az öszszeget minden évben növelni kellene az infláció mértékével vagy a gyermek szükségleteinek növekedésével arányosan. Például a magas iskolai végzettségú, városban élő Tamara, aki a párjával közösen egyezett meg a bíróság bevonása nélkül az összeg meghatározásban, említette is párjának: „Hát mondtam neki, hogy azért most 
már ha belegondolsz, lassan tíz éve ugyanaz az összeg”. A szintén magas iskolai végzettségű városban élő Barbara, akiknél bírósági döntés született a megállapodásról, szintén megemlítette a tartásdíj valorizációjának problémáját: „2005-ben ez a kétszer 20000 Ft nem volt olyan rossz, de ez a mai napig ennyi”.

A valorizáció problémáját csak a nők említették meg, azonban a férfiak részéről is volt kísérlet a tartásdíj változtatásának kieszközlésére. Például az érettségivel rendelkező, városban élő Dániel a különválás után új kapcsolatot alakított ki, amelyben újabb gyermeke született. Amikor jelenlegi felesége a második gyermekükkel terhes lett, erre hivatkozva szerette volna csökkenteni az előző kapcsolatból származó gyermek után fizetendő tartásdíj mértékét. „Felmerült, utánajártunk a témának, de talán valami $2 \%$-ot engednének el... szóval most $2 \%$ miatt nem fogok balhézni.. Ő az általa kevésnek ítélt csökkentés miatt nem kezdett bele a hosszas jogi procedúrába.

Dániellel ellentétben a magas iskolai végzettségú, fővárosban élő István jogi útra terelte a tartásdíj csökkentésének szándékát. Az ő esetében is meghúzódott az újabb gyermekvállalás a csökkentés szándéka mögött. Ezzel kapcsolatban István arról számolt be, hogy a bíróság nem vette figyelembe azt, hogy újabb gyermekről kell gondoskodnia: „Még az sem számított, hogy közben lett még egy gyerekem. Azt mondták, »minek fogadott örökbe?"” A másik ok, amelyre hivatkozott, az volt, hogy ténylegesen csökkent a jövedelme ahhoz képest, amikor a tartásdíj összegét a bíróság megállapította. „Nagyságrendekkel lecsökkent a jövedelmem a korábbiakhoz képest, ráadásul ugye egyetemre jártam, így nem is tudtam mellé föállást vállalni. Ebböl az lett, hogy kértem a tartásdij csökkentését, amire a bíróság egy nagyjából kétéves procedúra után nemet mondott. Tehát így két évig a magasabb összegú tartásdíjat kellett volna fizetni, de nem volt miból, így felgyúlt egy elég komoly összeg. Ráadásul nekem egy nagy összeg volt, 116000 Ft a két gyerekre a tartás díj 2008-tól.” Mivel a bíróság elutasította a kérelmét, jelentős tartásdíjhátralékot halmozott fel, amelyből rendőrségi ügy lett. Ennek következtében 140 nap közhasznú munkára ítélték. Erre azonban nem került sor, mert ekkor úgy döntött, hogy egy összegben rendezi - ingatlanátruházással - a tartásdíj fizetését, amire a 2014-ben hatályba lépett új Ptk. lehetőséget teremtett.

Összességében az mondható el, hogy bár az anyák részéről volt törekvés a tartásdíj valorizációjára, ám egy esetben sem jártak sikerrel. Az apák közül ketten szerették volna jelentősen csökkenteni a tartásdíj összegét, de ez sem következett be a hosszú és rugalmatlan jogi procedúrák miatt. A tartásdíj összege így szinte konstansnak tekinthető, ami nagyfokú elégedetlenséggel jár együtt az érintettek körében.

\section{A gyermekkel történö kapcsolattartás a gyakorlatban}

A korábban elterjedt kéthetente hétvégi kapcsolattartás gyakorlata nem volt jellemző a mintánkban: az eseteink mindössze egyharmadában született ilyen megállapodás, az esetek többségében pedig ettől jelentősen eltértek. Bár az esetek túlnyomó többségében ennél kevesebbszer találkoztak, azonban arra is volt példa, hogy sokkal intenzívebb kapcsolattartás jött létre, mint a korábban elterjedt mintázat. 


\section{Ritka találkozások}

Mintákban a legkirívóbb eset az alacsony iskolai végzettségű, faluban élő Gézáé, aki teljesen elzárkózott attól, hogy felvegye a kapcsolatot tizenéves lányával, annak ellenére, hogy a lánya többször megkereste őt kapcsolatfelvétel céljából. Sőt a tizenéves kislány Géza elmondása szerint egy közösségi portálon keresztül a féltestvéreivel és Géza új élettársával is próbált kapcsolatot létesíteni. A kapcsolatfelvétel elutasítását azzal indokolta Géza, hogy „Nem akarok belefolyni, mert szerintem biztos, hogy nem az enyém". Habár bizonytalan, hogy valójában ő-e a kislány biológiai apja, ódzkodik a DNS-vizsgálat elvégzésétől, és inkább havonta fizet egy kisebb összeget gyermektartásként, amelyről informálisan egyeztek meg volt párjával. Az alacsony iskolai végzettségű, falun élő Szabolcs szintén nem ápol szoros kapcsolatot a kamasz gyermekével: havonta egyszer találkozik vele, amikor személyesen neki adja át a tartásdíj összegét. Ezekről a találkozásokról így számol be: „Hát úgy van, hogy én általában havonta megyek hozzá, amikor elviszem a pénzt. A lehetőség adott neki, én nem vagyok elzárkózva (...) de úgy érzem, hogy nem csak nekem kéne”. Szabolcs tehát úgy véli, hogy a gyermeknek kellene proaktívan kezdeményeznie a kapcsolattartást vele, és az ő részéről a kapcsolattartás kimerül a tartásdíj személyes átadásában. A szintén alacsony iskolai végzettséggel rendelkező, falun élő Ágnes is arról számolt be, hogy volt párja nem törődik a lányával. Miután külön költözésük után egy évvel bírósági úton kikényszerítette a tartásdíj fizetését, a bíróság a kapcsolattartásról is határozott: „onnantól kezdve eszébe jutott, hogy akkor neki joga van kéthetente látni a lányát”. Azonban ekkor a kapcsolttartás nem volt zökkenőmentes, mert a kislány nem akart találkozni az apjával, és akkor az apa rendőrt hívott, hogy kikényszerítse a gyermek láthatását. Ez nem sikerült, mivel ez a kérdés nem a rendőrség kompetenciája, hanem a gyámhivatalé. Később pedig a kislány mégis úgy döntött, hogy tartani szeretné a kapcsolatot az apjával, így nem került sor a gyámhivatal bevonására.

Az érettségivel rendelkező Petráéknál annyiban speciális a helyzet, hogy ott a nő külföldi munkavégzése miatt szakadt meg a kapcsolattartás a gyermekeivel. Petra volt férje, Péter erről a következőképpen számol be: „az elmúlt nyolc évben háromszor látta őket... ez katasztrofális”. Ráadásul ebben az esetben is a gyermekek részéről merült fel, hogy négy év elteltével szeretnének találkozni az édesanyjukkal. Erre végül is Péter teremtette elő az anyagi forrást, így ők látogatták meg az anyát külföldön.

A magas iskolai végzettségű, fővárosban élő Kornélnál a bíróság lehetővé tette volna, hogy kéthetente egy hétvégén és egy hétköznap találkozzon a gyermekeivel, de Kornél elmondása szerint „nem használtam ki ezt a dolgot”. Az előző esethez hasonlóan Kornél is messzebbre költözött a gyermekeitől egy bizonyos idő elteltével, de nála a költözés előtti időszakban sem volt jellemző a gyakoribb találkozás. Az ő esetében az elköltözés új párkapcsolat kialakításával is járt, amely pozitívan hatott a gyerekekkel való találkozások gyakoriságára. Kornél arról is beszámolt, hogy a gyermekek életkorának előrehaladtával a találkozások száma azonban még inkább csökkent. „Most már gyakorlatilag csak a legkisebb gyermekemmel, a lányommal van rendsze- 
res találkozás." Ez a mintázat több esetben is megfigyelhető, több interjúalanyunk is arról számolt be, hogy már csak a kisebb gyermekével van intenzív kapcsolata. Kornél és kislánya rendszeres találkozását az is elősegíti, hogy a gyermeket felváltva viszi hozzá volt felesége és annak férje, illetve Kornél. Ebben azért állapodtak meg így, hogy ne az apára háruljon az utazási költségek egésze, valamint, hogy az utazással járó nehézségek ne álljon útjába a rendszeres találkozásoknak.

\section{A kapcsolattartás alakulása a gyermekek életkorának függvényében}

A találkozások száma és a gyermekek életkora közötti kapcsolatban két mintázat figyelhető meg. Az egyik a korábban említett életkor növekedésével csökkenő találkozások száma. Különösen a kamasz gyerekeknél figyelhető meg, hogy eltávolodnak a különélő szülőktől, mert felértékelődik a kortárs csoporttal töltött idő, amit legtöbbször nem is sérelmeznek az apukák.

A városban élő, magas iskolai végzettségű Barnabás például aktív lépéseket tesz annak érdekében, hogy „versenyképes” maradjon a kortárs csoporttal. „Most ezek, úgy érzem, hogy nekem lettek fontosabbak [a találkozások], így most ezt nekem kell életben tartanom: kitalálni olyan programokat, ami számukra érdekes, felhívni őket, stb. De egyelöre nehéz vetélkedni a saját baráti körükkel, most, hogy kamaszok lettek, ez sokszor nem is sikerül. Ez a kéthetente találkozunk ütem ez teljesen meg is szünt.” A fővárosi, magas iskolai végzettségü Fülöp kamaszkorú gyermekei is egyre több időt szenteltek a baráti kapcsolatoknak, de ezzel Fülöp nem is akart versenyezni: „Én mindig propagáltam, tehát ha olyan ütközés merült fel időben, hogy most életkori társaságba menjenek vagy hozzám jöjjenek, akkor én a legtöbbször biztattam öket, hogy az életkori társasággal tartsák a kapcsolatot. Tehát hogy az szerintem fontosabb, mint a távollévő szülővel való kapcsolat."

Dániel pedig azzal próbálta elősegíteni a kamasz fiával való kapcsolattartást, aki egy másik városban élt, hogy meghívta hozzájuk az iskolai szünetben nemcsak a fiát, hanem annak legjobb barátját is. Nagyon hálás a mostani feleségének, hogy ebben együttmúködött vele, és ő is örömmel látta a fiúkat. Ennek ellenére volt párja - az alacsony iskolai végzettségű Daniella - úgy látja, hogy „amióta a fiam kamasz, nem nagyon akar menni az apjához, de ez azért is van, mert az apja új felesége kiutálta ôt”. Ezeken kívül is minden kamasz gyermeket nevelő különélő szülő megtapasztalta a találkozások számának megritkulását kamaszkorban, de a legtöbben semlegesen álltak a jelenséghez és elfogadták azt.

A másik jellegzetessége a kapcsolattartásnak az életkor függvényében, hogy nem csak abban nő a gyerek autonómiája, hogy eldöntheti, mikor szeretne találkozni a különélő szülővel, hanem bizonyos életkor felett akár önállóan is meglátogathatja a különélő szülőt. A közepes iskolai végzettségű, városban élő Dániel esetében míg a fia kisebb volt, a találkozások számát erősen befolyásolta a távolság és az azzal járó útiköltség. Dániel erről így számolt be: „Nagyon drága volt ugye, hogy autóval felmenni érte mindig, lehozni, aztán visszahozni”. A gyermek anyjával kötött megállapodásuk szerint a fiú az általános iskolai ballagása után egyedül is meglátogathatta apját, amiről Dániel pozitívan nyilatkozik: „Mióta vonattal jár, az nekem sokkal könnyebb, mert így kifizetek 
neki kb. 1400 Ft-ot a jegyre, amikor meg még kocsival mentem, akkor fizettem olyan 12 ezer Ft-ot benzinre”. Dánielék példája jól demonstrálja, hogy a gyermekek serdülővé válásának több olyan dimenziója is van, amely befolyásolja a kapcsolattartás gyakoriságát.

A kapcsolattartás másik jellegzetes mintázata sokkal genderspecifikusabb: a kisgyerektől különélő apák legtöbbször azt tapasztalják, hogy az anya korlátozza a kapcsolattartást. E mögött általában az áll, hogy az anyák úgy érzik, az apának nincs kellő kompetenciája ahhoz, hogy egy kisgyermekről önállóan gondoskodjon. A közepes iskolai végzettségú, fővárosban élő Tamásnál például nem aludt ott a gyermeke addig, amíg óvodás korú nem lett. Erről így számol be: „Hétvégén meg egy napot áldoztam rá. Igaz, nem aludt nálam, de hoztam, majd visszavittem. Aztán utána óvodás korában aludt nálam". Ezt ő maga is természetesnek véli, mert azt gondolja, hogy egy kisgyerekről az anya tud jól gondoskodni. Ebben az esetben Tamás volt párja, Tamara is így vélekedett, és az ő beszámolója szerint is 4-5 éves lehetett a kisfia, amikor először az apjánál aludhatott.

A magas iskolai végzettségű, falun élő Erikéknél a gyermek négy hónapos volt, amikor a szülők párkapcsolata felbomlott. Erik költözött ki a házból, ahol a volt párjával és annak szüleivel élt korábban. Bár Eriknek rendkívül rossz érzés volt visszamenni abba a házba, de Erika ragaszkodott ahhoz, hogy csak és kizárólag náluk találkozhat a gyerekével: „Abban állapodtunk meg, hogy az egyik héten úgy láthatja, hogy szerdán délután 5-től 7-ig, a következő héten meg szombaton reggeltől altatásidőszakig, utána visszajöhet, amikor fölkel, akkor megint estig, de mindezt nálunk.” Teljes mértékben elzárkózott attól, hogy házon kívülre vigye az apa a gyereket, amit a következővel indokolt: „Azért, mert féltem töle, hogy mit csinál vele. Olyan sok rossz hír van, hogy az apa elviszi a gyereket, nem hozza vissza, és akkor gyere velem össze, nem adom vissza a gyerekedet, tehát ettól tartottam nagyon." Ebben megmutatkozik egyrészt az is, hogy kevés idő telt el a kapcsolat felbomlása után, így nagyon intenzívek voltak még az érzelmek, másrészt a párkapcsolati erőszak ezen formájától való félelem is megnyilvánul, amely Erika részéről nem alaptalan. Az anya beszámolt róla, hogy az egyik látogatás alkalmával Erik a falhoz szorította ôt és szexuálisan bántalmazta. Olyan alternatíva is felmerült a tárgyaláson, hogy mediátor bevonásával egy semleges helyen történjen az apa és gyermeke közötti kapcsolattartás. Erre szolgálna egyébként a Család- és Gyermekjóléti Központok által biztosított kapcsolati ügyelet intézménye, amely lehetőséget biztosít a gyermek és a kapcsolattartásra jogosult szülő találkozására a felek számára semleges helyszínen. A kapcsolattartás zökkenőmentes lebonyolítását szakemberek segítik. Ezt a szolgáltatást térítésmentesen lehet igénybe venni bírósági végzést, gyámhivatali határozatot vagy önkéntes jelentkezést követően - a szülők mediációs megállapodása alapján (MAKAMOSZ 2007). Erika azonban ettől is elzárkózott, attól tartva, hogy egy pár hónapos gyereknek nem jó, ha idegen helyen tartózkodik az apa kényelmének érdekében. A szülők közötti konfliktus következtében Erik ebben az időszakban kevesebbszer találkozott a gyermekével, mint ahányszor lehetősége nyílt volna a jogi végzés szerint. Ez azonban idővel 
változott, amikor a szülők kapcsolata stabilizálódott. Náluk is a gyermek óvodás kora volt a vízválasztó a kapcsolattartásban. Erik ekkortól elviheti a gyermeket a saját házukba több órára is, azonban éjszaka még nem alhat ott. Ezt Erik is elfogadja, hiszen a gyermek nagyon ragaszkodik az anyjához, viszont várja már a következő nyarat, és bízik abban, hogy már éjszaka is nála aludhat a lánya.

$\mathrm{Az}$ alacsony iskolai végzettségű, falun élő Ágneseknél némileg eltérő a helyzet, mert 15 éves lányuk az utóbbi időben ragaszkodik az apjához és szívesen aludna nála minden második hétvégén, de az ottalvást a lány kamaszkora óta Ágnes nem engedélyezi. Ezt a következővel indokolja: „Hát, szokott ott aludni, de az utóbbi hónapokban már mondtam, hogy nem. Milyen dolog az egy 15 éves lánynak, hogy az apjával aludjon egy ágyban? Én nem engedem, hogy ott aludjon. Tiszteletben kéne a gyerekét tartani, hogy veszek neki egy ágyat. Még hogy egy szobában, az még hagyján, de nem egy ágyban." Ágnes többször kihangsúlyozza azt, hogy egyáltalán nem tart a szexuális abúzus lehetőségétől, mert jól ismeri a volt párját és megbízik benne. Egyszerúen csak „nem illik” olyat tenni, hogy egy apa egy ágyban alszik a kamasz lányával. Ebben az esetben is a kamaszkor az oka a kevésbé intenzív találkozásoknak, bár ez nem a gyermek részéről következik be, hanem az anya nyomására.

Összegezve, az interjúkból az derül ki, hogy a legrendszeresebb kapcsolattartás az óvodás és a kamaszkor közötti időszakban alakul ki a gyermek és a különélő szülő között, amit több apa maga is megfigyelt. Ekkor általában már nem kérdés, hogy ott aludhat-e a gyermek, és a gyerekek is szívesebben töltenek idôt a szüleikkel. A gyermekekkel együtt élő szülők (általában anyák) is ebben az időszakban támogatják leginkább a kapcsolatot, aminek hátterében az is állhat, hogy a gyermek életkorának növekedésével csökken az a társadalmi nyomás, miszerint nekik kell betölteniük a kizárólagos gondozói szerepet. Több anya is, aki ilyen idős gyereket nevelt, beszámolt arról, hogy milyen könnyebbséget jelentett az apa részvétele a gyermek gondozásában. A magas iskolai végzettségű, fővárosban élő Alexandra a következőképpen beszélt erről: „A leírtak szerint egy héten két délután és minden második hétvége. Aztán én kértem töle segítséget, először nem akart, de aztán rájött, hogy az neki sem rossz. Úgyhogy nem csak heti két délután, hanem ott is alszanak nála, meg minden második hétvége, szóval sokat vannak vele. (...) meg szerettem volna azért magamat is megélni”. Hasonlóan vélekedik erről a magasi iskolai végzettségű fővárosban élő Csenge is, aki emiatt döntött a váltott gyermekfelügyelet intézménye mellett.

\section{A gyermekfelügyelet, a kapcsolattartás és a tartásdij fizetése közötti lehet- séges interakciók}

Nemcsak külön-külön érdemes vizsgálni a gyermekfelügyelet, a tartásdíj és a kapcsolattartás kérdését, hanem azok interakcióit is érdemes figyelembe venni. Korábbi kutatások is felhívták már a figyelmet arra, hogy szoros kapcsolatban áll a tartásdíj fizetésének kérdése a láthatósággal mind a nők, mind a férfiak részéről. A férfiak részéről általános az a vélekedés, hogy a tartásdíj fizetésével „megvásárolják” a gyer- 
mek láthatóságát is. A legszorosabb összefüggést az alacsony iskolai végzettségú, falun élő Szabolcséknál találtuk, ahol konkrétan a tartásdíj személyes transzferére redukálódott a kapcsolattartás. A szintén alacsony iskolai végzettségű, falun élő Ágnes is arról számolt be, hogy amikor a bíróság megállapította a tartásdíjfizetési kötelezettséget az apának, „onnantól kezdve eszébe jutott, hogy akkor neki joga van kéthetente látni a lányát, és addig miért nem jutott eszébe?”.

A külföldön élő, közepes iskolai végzettségű Petráéknál is összefüggést találtunk a kapcsolattartás és a tartásdíjfizetés között. Amikor Petra külföldre költözött és Péter vette át a gyermekek elsődleges felügyeleti jogát, Petra tartásdíjat fizetett Péternek. Erről így számolt be: „Anno amikor elváltunk, akkor a bíróság automatikusan megállapitott egy összeget, mert ugye ez minden esetben így történik. És fizette. És amikor a szerepek megcserélődtek, én is ugyanannyit fizettem." Mivel Petra Amerikába költözött, ezért a gyermekekkel nagyon ritkán találkozott (8 év alatt mindössze háromszor). A találkozások elmaradásával együtt a tartásdíj fizetése is elmaradt. Petra erről a következőket mondta: „Az az igazság, hogy tartásdíjat így konkrétan minden hónapban nem is fizetek már régóta." Azonban az anyagi támogatás mégis összefügg Petráék esetében is a kapcsolattartással, erről így számol be Petra: „Ha pénz kell neki [a fiának], akkor felhív skype-on, és én mindig utalok."

A magas iskolai végzettségű, falun élő Eriknél a tartásdíj fizetése összekapcsolódik azzal, hogy rugalmasan láthassa a kislányát: „Ha már van X összeg havonta, akkor ne legyen szabályozva, hogy mikor láthatom”. A magas iskolai végzettségű, fővárosban élő Fülöp azt mesélte, hogy a szétköltözést követően az anyuka addig nem engedte a gyermekkel történő kapcsolttartást, amíg ő maga alá nem írta, hogy a gyermekgondozás anyagi költségeit hogyan fogják megosztani. Emellett a nők részéről is sokszor megfigyelhető az a leegyszerúsített álláspont, hogy akkor van joga az apának a gyermeket látni, ha rendszeresen fizeti a tartásdíjat. Niki például egészen addig nem engedte, hogy volt párja lássa a gyermeket, amíg a bíróság nem döntött a tartásdíj mértékéről. Erről ő maga a következőt mondta: „Ő [volt férje] adta be egyébként a biróságra a kérvényt, hogy ő csak 50 ezret [tartásdíjat] akar fizetni. Én is beadtam volna a kérvényt, de megelözött. Meg ö ugye azért is adta be olyan gyorsan, mert én meg nem nagyon engedtem, hogy lássa a gyereket". A tartásdíj és a kapcsolattartás közötti problémára már a Joggyakorlat Elemző Csoport is felhívta a figyelmet, és hangsúlyozzák, hogy amennyiben valamelyik fél bizonyíthatóan alku tárgyává teszi a kapcsolattartást vagy a tartásdíj fizetését, azt a terhére lehet értékelni (Joggyakorlat Elemző Csoport 2018).

Ugyanakkor az intenzívebb és rugalmasabb kapcsolattartás a gyermek és a különélő szülő között sokszor azzal is járt, hogy az apák a megállapított tartásdíjon felül is támogatták anyagilag a gyermekeiket. Például a magas iskolai végzettségű István - akinél a gyerekek sok időt töltenek - úgy látja, hogy az egyik különélő fia nagyon tehetséges rajzból, ezért rajzszakkörre járatja, de ennek költségét egyedül kell állnia, mert a volt felesége ezt nem tartja fontosnak, és abba sem egyezett bele, hogy 
ennek költségét levonják a tartásdíjból. A szintén fővárosban élő, magas iskolai végzettségű Alex is szoros kapcsolatot ápol a két nem vele élő gyermekével, és ő maga szintén rendszeresen fizet egyéb költségeket gyermekei számára a tartásdíjon felül. „Ha a lányom vagy a fiam mondja, hogy ezt kellene venni, erre van szükség az iskolában, akkor azt megveszem, és nem viszem róla a számlát. Ilyen szempontból próbálok nagyvonalú lenni, és még a látszatát is el szeretném kerülni annak, hogy a gyerekek azt érezzék, hogy bármilyen ilyenfajta igényükre azt mondjam, hogy majd az anyátok kifizeti, mert én fizetem a tartásdíjat”. Ô ezt azzal indokolja, hogy anyagilag megteheti, és nem akarja, hogy a gyermekek ilyenfajta veszekedéseket észleljenek.

$\mathrm{Az}$ érettségivel rendelkező, városban élő Tamás is a szétköltözés óta (kétéves volt akkor a gyermekük) folyamatosan szoros kapcsolatban van a most 10 éves fiával: szinte mindennap beszélnek telefonon, és egy héten többször találkoznak személyesen. Tamás is anyagilag többel járul hozzá a gyermeknevelés költségeihez, mint a tartásdíjban megállapított összeg. Ő fizeti például a gyermek németóráit, és gyakran nagyobb kiadással járó ruhanemúket (nagykabát) és cipőt is vesz neki. A válás utáni időszakban kevesebbszer kommunikáltak volt párjával, Tamarával, ezért előfordult, hogy olyan ruhadarabokat vett a fiának, amelyekre egyébként nem volt szükség. Tamara a következő példával illusztrálta a problémát:,...nem szólt, hanem valamiket vett, és utána kezdtem vele [a gyerekkel] visszahordatni, mert kicsit vett, nyilván nem tudta, hogy van mondjuk 3 kabátja, tehát vett még egyet, tehát ezek azok, amik ilyen feleslegesek, mert nem kérdezett. Mindig mondtam, hogy kérdezd meg, most már megkérdezi”. Később jó szülői viszony jött létre Tamara és Tamás között, így megoldódott köztük a fenti probléma.

Amennyiben a különélő szülő és a gyermeke között nem valósul meg a kapcsolattartás vagy az csak a kötelező láthatásra korlátozódik, akkor a tartásdíj fizetésen kívül nem kerül sor plusz anyagi támogatásra az apa részéről. Például a magas iskolai végzettségü, falun élő Erik, illetve az alacsony iskolai végzettségű, falun élő Szabolcs és Géza esete is ide sorolható.

Az interjúk arra is rávilágítottak, hogy a tartásdíj és a gyermekfelügyelet kérdése is némiképp összefügghet. Például Csongor azért egyezett bele a váltott gyermekfelügyeletbe, hogy elkerülje a tartásdíj fizetését. „Ebből a tartási kérdésből rengeteg konfliktus volt... Úgy voltam vele, hogy akkor leszek én is a gyerekkel, de bébiszittert nem támogatok." Habár a másik váltott gyermekfelügyeletet választó interjúalanyunk arról számolt be, hogy ő annak ellenére, hogy a gyermekek az idő felét nála töltik, fizet tartásdíjat. Az ő esetükben a tartásdíjfizetésre azért került sor, mert jelentős életszínvonalbeli különbség van a felek között.

A közös gyermekfelügyelet azt jelenti, hogy mindkét fél részt vesz a gyermek életét érintő fontos döntések meghozatalában. Az interjúalanyok beszámolói alapján ez azonban ritkán valósul meg, még abban az esetben is, ha az apa rendszeresen tartja a kapcsolatot a gyermekével. Például a magas iskolai végzettségű Tamara arról számolt be, hogy tudatosan egyedül döntött arról, hogy másik iskolába íratja be 
a fiát: „Nagyon nem hagytam választást, tehát vasárnap felhívtam, hogy hétfön megyek a gyerek papirjaiért és ki fogom venni és hova fogom vinni. Ez már egy három-négy hete érlelődött bennem, így igazán nem is akartam erre lehetöséget adni, hogy lebeszéljen róla, mert én annyira százszázalékosan éreztem, hogy ezt nem most, már előbb meg kellett volna tenni”. Az érettségivel rendelkező Tamás pedig elfogadta, hogy a gyermekét érintő döntésekbe nincs beleszólása, csak utólagos tájékoztatást kap: „Édesanyja utólagosan tájékoztat ezekről a dolgokról, amikor meghozta a döntést. Nekem néhány döntésben más a véleményem, de mivel napi szinten ö hozza meg az áldozatokat, ezért mondtam neki, hogy jó, te hozod az áldozatot, te döntesz".

A magas iskolai végzettségú Fülöp szinten úgy látja, hogy őt volt felesége teljesen kizárja a gyermekkel kapcsolatos döntésekből és csak utólagos tájékoztatást kap, holott szeretett volna részese lenni a döntésnek, és ő más véleményt képviselt, mint volt párja például az iskolaválasztás tekintetében: „A fiam iskolaváltásánál én szerettem volna balanszírozni, hogy nem feltétlenül... Én nem vagyok ilyen feladós (...). Én mindent végig szeretek nyomni, és ezt szerettem volna a fiamnak is, hogy még kínlódjál tovább 2 évet a matekkal, de mindent a volt feleségem dönt el”. A főiskolai végzettségű Barnabás is úgy érzi, figyelmen kívül hagyták a véleményét a középiskola kiválasztásakor, holott úgy érzi, vállalkozóként kompetens lett volna ebben a kérdéskörben: „Nem tudtam beleszólni már, pedig vállalkozóként tudom, mi az, ami a piacon jobban eladható szakma, stb. A gyerekek kitaláltak valamit, és a feleségem azt az irányt hagyta jóvá, támogatta, így most olyan iskolába járnak, amivel tudom, hogy a valós életben nem lehet boldogulni”. Habár ebben az esetben nem a gyerekkel együtt élő szülő volt a fő döntéshozó, hanem maguk a gyerekek. Érdekes, hogy Barnabás volt párja, Barbara másképp látja a döntéshozatal folyamatát: „Hát meg szoktam vele osztani, megmondom, hogy mit akar a gyerek, de olyan nagyon mélyen nem megyünk bele. Sokszor éreztem úgy, hogy a döntéseimben egyedül vagyok. A lányom iskolaválasztásába szólt bele, hogy ne járjon olyanba, ahol sok a kisebbségi. ... De ennyi volt, hogy csak abba az iskolába nem, de máshova meg mehet, amit persze én intézzek el, onnantól neki mindegy volt”. Mindezek a példák azt tükrözik, hogy hiába ápolnak jó partneri viszonyt egymással a szülők és hiába van intenzív kapcsolat a különélő szülő és a gyermeke között, a fontosabb döntések meghozatalában általában a gyermekkel élő szülő nagyobb mértékben vesz részt, mint a különélő szülő.

Miközben azok a szülők, akik kevésbé szoros kapcsolatot ápolnak a gyermekükkel, szinte teljesen kimaradnak a gyermeket érintő döntések meghozatalából. Az alacsony iskolai végzettségű, falun élő Szabolcs a középiskola kiválasztásával kapcsolatban úgy látta, hogy „nyilván a jobban ráható személy az a mostani srác volt, akivel az anyja együtt él”. Azaz a volt párja jelenlegi partnere, aki jelenleg együtt él Szabolcs gyermekével, nagyobb mértékben vett részt a döntés meghozatalában, mint maga az apa. Az alacsony iskolai végzettségú Ágnes szintén úgy látja, hogy volt párja egyáltalán nem vesz részt a fontosabb döntések meghozatalában: „...mindent csak mi ketten beszélünk meg a lányommal”. 
A váltott gyermekfelügyelet azonban mindenképpen előnyös a gyermek életében való részvételt illetően hiszen mindkét szülő együtt él a gyermekkel, ebből következően egyikük sem marad ki a döntések meghozatalából. Ráadásul a szülők rendszeresen együttmúködnek, kommunikálnak egymással, igy a konszenzusra törekvés nem idegen tőlük. Habár ekkor is lehetnek egyenlőtlenségek, például a magas iskolai végzettségű, fővárosban élő Alfréd úgy látja, hogy „a nagy döntésekben konszenzus kellene, hogy legyen, de általában ö elég karakánul elmondja, mi legyen, szóval vannak még viták. Miközben vannak ilyen dolgok, ilyen atyai döntések, amiket el is vár, hogy én hozzak meg: pl. melyik iskolába járjon stb.". Ennek ellenére mindkét esetben, amikor a váltott gyermekfelügyeletre került sor, a szülők arról számoltak be, hogy ennek köszönhetően aktív részesei maradtak a gyermek életének, és együtt hozzák meg a gyermeket érintő fontosabb döntéseket.

\section{Összefoglaló}

Jelen kutatás azt mutatta be, hogy Magyarországon hogyan vesznek részt a különélő szülők a gyermekeik életében. Elsősorban három területet vizsgáltunk, amelyeket a magyar jogrendszer szigorúan szabályoz: a gyermekfelügyeletet, a tartásdíj fizetésének kérdéseit és a gyermekkel való kapcsolattartást. Azt elemeztük a 17 esettanulmány (25 interjú) alapján, hogy mindezek a jogilag jól szabályozott kérdések hogyan valósulnak meg a gyakorlatban. A gyermekfelügyeleti jogok tekintetében jelentős változások következtek be 2014-től: az új polgári törvénykönyv (Ptk.) a közös szülői felügyeleti jogot tekinti főszabálynak, függetlenül attól, hogy a gyermek kivel él. Ezek a jogi változtatások mindenképpen pozitívnak tekinthetők és összhangban vannak a törődő apaság megjelenésével. Azonban az általunk vizsgált esetek arra világítanak rá, hogy ritkán valósul meg az, hogy mindkét szülő egyformán vesz részt a gyermeket érintő fontosabb döntések meghozatalában. Azt találtuk, hogy a különélő szülők nem tudnak, vagy nem is kívánnak beleszólni a velük nem együtt élő gyermekeiket érintő fontos kérdésekbe (mint például az iskolaválasztás). A váltott gyermekfelügyelet egyik előnye éppen az, hogy a közös szülő felügyeleti jogok ebben az esetben ténylegesen közös döntéseket jelenthetnek. Abban a két esetben, ahol váltott gyermekfelügyeletre került sor, mindkét szülő aktívan részt vett gyermekeik életében, ők maguk pedig partneri viszonyt tudtak kialakítani a szülőség tekintetében. Fontos lenne, hogy a jövőben a párkapcsolat felbomlását követően a kiskorú gyermeket nevelő szülők, amennyiben ez módjukban áll (megfelelő anyagi háttérrel rendelkeznek, közel élnek egymáshoz és képesek együttmúködni a gyermeknevelés kérdésében), a gyermekfelügyeletnek ezt a módját válasszák (Bjarnason-Arnarsson 2011). Ehhez fontos lenne, hogy megfelelő információ álljon a szülők rendelkezésre arról, milyen előnyökkel járhat, ha mindkét fél aktívan törődő szülő marad a párkapcsolat felbomlását követően is (pl. csökkenti a válás utáni stresszt a gyermekek körében) (Bjarnason-Arnarsson 2011). Bár egyre többen választják a váltott gyer- 
mekfelügyeletet a párkapcsolat felbomlása után Európában, különösen az északi országokban, ennek széles körű elterjedése nem várható Magyarországon, mivel a partnerkapcsolat felbomlását követően sokan lakhatási nehézségekkel szembesülnek (Murinkó 2019).

Mindenestere érdemes lenne megfontolni, hogy miként lehetne ösztönözni a kapcsolattartást, amennyiben a különélő szülő nem lakik egy településen a gyermekével. Ez azért is fontos kérdés, mert a korábbi kutatásokhoz hasonlóan mi is azt találtuk, hogy a kapcsolattartás gyakorisága összefügghet azzal, hogy milyen messze él a különélő szülő a gyermekétől. Az elemzésünk rávilágított arra, hogy anyagi problémát jelenthet a különélő szülőnek a gyermekével való kapcsolattartás, amennyiben más településen élnek. Norvégiában például 2003-tól a különélő szülő levonhatja az utazás költségét a tartásdíjból, amennyiben távol él gyermekétől (Kitterød-Lyngstad 2011).

Ezenkívül azt találtuk, hogy azok az apák, aki törődő apaként voltak jelent gyermekeik életében abban az időszakban, amikor még együtt éltek gyermekeikkel, a szétköltözés után is intenzívebb kapcsolatot tartanak a gyerekeikkel. Ez pedig azt jelezheti, hogy azok a családpolitikai intézkedések, amelyek az apákat ösztönöznénk a gyermekgondozásban való részvételre, mint például az EU által ajánlott irányelv a legalább kéthetes apai szabadságra vagy az apakvóta bevezetése a gyermekgondozásban, nemcsak az együtt élő párok életében járnának pozitív változással, hanem azoknak a szülőknek is segíthetnének, akik később egyedül nevelik a gyermekeiket.

Továbbá azt is megfigyeltük, hogy a kapcsolattartás intenzitása és gyakorisága összefügghet a gyermek életkorával is. Úgy tűnik, hogy az óvodás és a kamaszkor közötti időben áll fenn a legkevesebb kapcsolatot akadályozó tényező. Az interjúalanyok (mind a nők, mind a férfiak) arról számoltak be, hogy ebben az időszakban volt leginkább rendszeres a kapcsolattartás a különélő szülő és gyermeke között. E mögött az állhat, hogy az óvodáskorúnál fiatalabb gyermekeket az anyák nem szívesen bízzák az apára - és az apák is félnek attól, hogy nem tudnak mit kezdeni egy fiatalabb gyermekkel. A kamasz gyerekek pedig sokszor inkább a kortárscsoportok társaságát választják, ahelyett, hogy a különélő szülővel töltenék az idejüket.

A mintánk nem reprezentatív jellegú és önkéntes részvételen alapult, ennek következtében csak olyanok alanyok vállalták a kutatásban való részvételt, akik - legalábbis saját bevallásuk szerint - fizetnek tartásdíjat. Azaz a tartásdíj nem fizetését ebben a kutatásban kevésbé tudjuk vizsgálni. Ennek ellenére is több olyan esettel találkoztunk, amikor a különélő szülő nem megfelelő mértékben - vagy esetleg teljesen önkényesen - határozta meg, hogy mennyi tartásdíjat tud vagy hajlandó fizetni. További probléma, amelyre a kutatás rávilágított, hogy a formális úton kiszabott tartásdíj összege nehezen változtatható meg, valamint a tartásdíj értékének valorizációja nincs beépítve a rendszerbe, ami különösen fontos lenne az új Ptk. életbelépését követően, hiszen azóta nem százalékban, hanem fix összegben kell meghatározni a tartásdíj összegét. A hazai intézményrendszer alapos reformjára lenne 
szükség a tartásdíj (megfelelő mértékü) kikényszerítését illetően, mivel a hatékony szankciók bevezetésével ténylegesen csökkenthető lenne a gyermekszegénység kockázata. Továbbá észszerủ lenne olyan megoldásokat beépíteni a rendszerbe, amelyek figyelembe vennék a gyermek igényét is. Például Németországban a gyermek életkorától is függ a tartásdíj mértéke (Szepesházi 2010).

Fontos szerepe lehet a volt a szülők közötti kapcsolat minőségének is abban, hogy a különélő szülő miként tartja a kapcsolatot a gyerekkel, mennyire vesz részt a gyermek életét befolyásoló döntések meghozatalában és a tartásdíj fizetésében. Azoknál a feleknél, akik az interjú készítésekor is konfliktusos kapcsolatban álltak egymással, a kommunikáció hiánya olyan konfliktus helyzetekhez vezetett, amelyek akár negatívan befolyásolhatják a gyermekek érzelmi fejlődését. Míg azokban az esetekben, ahol partneri viszony alakult ki a szülőpárok között, gyakrabban és hatékonyabban kommunikáltak a tartásdij és a kapcsolattartás kérdésében és rugalmasan kezeltek egy esetlegesen felmerülő váratlan eseményt is (pl. a tartásdij fizetésének időleges elmaradása). Ezek alapján érdemes lenne a kapcsolatok felbomlása utáni időszakban lehetőséget adni a szülőknek arra, hogy kommunikációs tréningen vegyenek részt annak elősegítésére, hogy gyermekeik érdekét a saját vélt vagy tényleges sérelmeik fölé tudják helyezni. Jelenleg a rendszer egy alkalmas mediációt ajánl a feleknek a válás előtt, amennyiben kiskorú gyermeket nevelnek. Azonban egyetlen alkalom nem valószínủ, hogy segíteni tud a kívánt cél elérésében, azazhogy a szülők partnerként tudjanak együttmúködni.

Kutatásunk egyik erőssége, hogy nem csupán egymástól elkülönítve vizsgáltuk a három fontos kérdést: a gyermekfelügyeletet, a kapcsolttartást és a tartásdíjat, hanem azt is elemeztük, hogy milyen viszonyban állhatnak egymással. Ennek ellenére a kutatásunkban számos fontos kérdéskört nem vizsgáltunk. Például nem elemeztük mélyrehatóan, hogy az új partnerkapcsolat kialakításának milyen hatása lehet a különélő szülő és a gyermeke közötti kapcsolattatásra. Bár a korábbi kvantitatív kutatások azt találták, hogy a különéló szülő és gyermeke között a kapcsolattartás csökken, amennyiben valamelyik fél új kapcsolatot létesít, mi ezt nem figyeltük meg. Ennek az ellentmondásnak a vizsgálatára azonban további elemzésre lenne szükség. Szintén nem került be a kutatás fókuszába a nagyszülők szerepvállalásának kérdése, holott az új Ptk. szabályozza a nagyszülők kapcsolattartási jogát is, illetve ôk is kötelesek lehetnek gyerektartást fizetni bizonyos körülmények fennállása esetén. Érdekes kutatási irány lenne, ha a különélő szülő és gyermeke közötti kapcsolattartást aszerint vizsgálnánk, hogy a gyermek tervezett vagy nem tervezett volt-e a különélő szülő részéről, illetve, hogy vajon van-e kapcsolat aközött, hogy milyen párkapcsolati formában került sor a gyermekvállalásra. Ezeknek a kérdéseknek a vizsgálatára vagy azért nem kerülhetett sor, mert nem fért volna jelen tanulmányunk terjedelmi keretébe, vagy pedig egyszerúen nem állt módunkban, mivel ezeknek a kérdéseknek az elemzéséhez nagyobb mintára lenne szükségünk. Ezeket a kutatási irányokat 
mindenképpen érdemes a jövőben vizsgálni ahhoz, hogy jobban megértsük a különélő szülő és gyermeke közötti kapcsolattartás folyamatát.

\begin{abstract}
Significant changes have taken place in the lives of families in the last decades in Hungary. The number of divorces is on the rise as well as the termination of cohabiting relationships. In the meantime, the role of fathers is changing as they are increasingly involved in the lives of their children both instrumentally and emotionally. The purpose of this study is to examine the ways in which single parents (mostly fathers) are involved in the lives of their children and how parental custody, visitation and child support are implemented. It is important to examine this topic from a sociological approach because this perspective has been neglected in Hungary and the topic had not been observed sociologically before. Furthermore, a new Civil Code was enacted in Hungary in 2014 which brought significant changes regarding the regulation of parental custody and child support.
\end{abstract}

Keywords: custody, visitation, child support, role of non-resident fathers, semi-structured interviews

\title{
Irodalom
}

Amato, P. - Gilbreth, J. (1999): Nonresident fathers and children's well-being: A metaanalysis. Journal of Marriage and Family, 61(3), 557-573. doi:10.2307/353560.

Arditti, J. A. - Keith, T. Z. (1993): Visitation frequency, child support payment, and the father-child relationship postdivorce. Journal of Marriage and the Family, 55, 699-712.

Barber J. - Evans A. (2006): The Intersection Among Unintended, Premarital, and Teenage Childbearing in the U.S. Report 06-608. Population Studies Center.

Bauserman, R. (2002): Child adjustment in joint-custody versus sole custody arrangements: A meta analytic review. Journal of Family Psychology, 1, 91-102. doi:10.1037/0893-3200.16.1.9

Bjarnason, T. -Arnarsson, A. (2011): Joint Physical Custody and Communication with Parents: A Cross-National Study of Children in 36 Western Countries. Journal of Comparative Family Studies, 42(6), 871-890. Retrieved from www.jstor.org/ stable/4160449

Cheadle, J. E. - Amato, P. R. - King, V. (2010): Patterns of Nonresident Father Contact. Demography, 47(1), 205-225.

Crompton R. - Lyonette C. (2005): The new gender essentialism - domestic and family 'choices' and their relation to attitudes. British Journal of Sociology 56(4), 601-24.

Dénesné Orcsik J. (2017): Amikor csak az egyik szülőé a felügyeleti jog. https:// jogaszvilag.hu/szakma/amikor-csak-az-egyik-szuloe-a-felugyeleti-jog/ 26 Letöltve: 2019. június 10.

Dermott, E. (2003): The'Intimate Father': Defining Paternal Involvement. Sociological Research Online, 8(4), http://www.socresonline.org.uk/8/4/dermott.html. 
Dermott, E., - Miller, T. (2015): More than the Sum of Its Parts? Contemporary Fatherhood Policy, Practice and Discourse. Fathers, Relationships and Societies,4(2), 183-195. https://doi.org/10.1332/204674315X14212269138324

Donnelly, D. - Finkelhor, D. (1993): Who Has Joint Custody? Class Differences in the Determination of Custody Arrangements. Family Relations, 42(1), 57-60.

Földházi E. - Murinkó L. (2012): Háztartás- és családszerkezet. In Őri Péter - Spéder Zsolt (szerk.): Demográfiai Portré 2012. KSH NKI, Budapest, 113-123.

Gibson-Davis, C. M. (2008): Family Structure Effects on Maternal and Paternal Parenting in Low-Income Families, Journal of Marriage and Family, 70, 452-465.

Goldberg J. S. (2015): Coparenting and Nonresident Fathers' Monetary Contributions to Their Children. Journal of marriage and the family,77(3), 612-627. doi:10.1111/ jomf.12191

Goldberg, J. S. - Carlson, M. J. (2015): Patterns and predictors of coparenting after unmarried parents part. Journal of Family Psychology, 29(3), 416-426. doi:10.1037/fam0000078

Joggyakorlat Elemző Csoport (2018): Összefoglaló vélemény a rokontartás szabályaival kapcsolatos ítélkezési gyakorlatról. Letöltve: 2019. május 20.

Kapitány, B. (2015): Demográfiai fogalomtár: KSH Népességtudományi Kutatóintézet, Budapest. https://www.demografia.hu/hu/letoltes/kiadvanyok/ Demografiai-Fogalomtar.pdf Letöltve: 2019. június 20.

Kitterød, R. H. - Lyngstad, J. (2011): Untraditional caring arrangements among parents living apart. The case of Norway. Discussion Papers No. 660. https:// www.ssb.no/a/publikasjoner/pdf/DP/dp660.pdf Letöltve: 2019. december 6 .

KSH (2019) : A felbontott és érvénytelenített házasságok a közös kiskorú gyermeke száma és elhelyezése szerint egyedi kérésre összeállított táblázatos adatállomány Központi Statisztikai Hivatal (www.ksh.hu)

Lindberg, L. D. - Kost, K. - Maddow-Zimet, I. (2017): The Role of Men's Childbearing Intentions in Father Involvement. Family Relations, 79(1), 44-59.

MAKAMOSZ (2007). Kapcsolattartási ügyelet/ kapcsolatügyelet szakmai protokoll. http://www.pszichoerdek.hu/protokollok/iskola/MAKAMOSZ_ medi\%C3\%A1ci\%C3\%B3s\%20protokoll.pdf Letöltve: 2019.11.26.

Makay Zs. - Szabó L. (2018): Válás. In Monostori Judit - Őri Péter - Spéder Zsolt (szerk.): Demográfiai Portré 2018. Jelentés a magyar népesség helyzetéről. KSH Népességtudományi Kutatóintézet, Budapest, 29-45.

Manning, W. D., - Stewart, S. D., - Smock, P. J. (2003): The Complexity Of Fathers' Parenting Responsibilities And Involvement With Nonresident Children. Journal of Family Issues, 24(5), 645-667.

Meggiolaro, S., - Ongaro, F. (2015): Non-resident parent-child contact after marital dissolution and parental repartnering: Evidence from Italy. Demographic Research, 33(40), 1138-1148. DOI: 10.4054/DemRes.2015.33.40 
Monostori, J. (2015): Az egyszülős családdá válás az életútban és annak demográfiai meghatározói. Demográfia, 58(1), 27-56.

Monostori, J. (2019): Egyszülős családok és politikák Magyarországon és Európában. Demográfia, 62(1), 5-41.

Moyal, A. (1992): The Gendered Use of the Telephone: An Australian Case Study. Media, Culture and Society,14,51-72.

Murinkó, L. - Szalma, I. (2015): Men's Fertility in Second Unions in Three European Countries: The Effect of Parenthood Status, Finnish Yearbook of Population Research, 50, 53-70.

Murinkó, L. - Szalma, I. (2016): Fatherhood and men's second union formation: Norway, France, and Hungary, 1980-2000. In Mortelmans, D. - Matthijs, K. Alof, E. - Segaert B. (eds.), Changing family dynamics and demographic evolution: The family kaleidoscope Cheltenham: Elgar, 179-213.

Murinkó, L. (2019): Housing consequences of divorce and separation in a super home ownership' regime: The case of Hungary. Demographic Research, 40(34), 975-1014.

Natalier, K. - Hewitt, B. (2010): It's Not Just About Money: Non-resident Father's Perspectives on Paying Child Support. Sociology, 44(3), 489-505. doi. org/10.1177/0038038510362470

Nielsen, L. (2011): Shared Parenting After Divorce: A Review of Shared Residential Parenting Research, Journal of Divorce \&; Remarriage, 52(8), 586-609.

OECD Child Support (2010) https://www.oecd.org/els/family/41920285.pdf Letöltve: 2019. június 20.

Parke, R.D. (1996): Fatherhood. Cambridge, MA: Harvard University Press

Patrick C. - McKenry, M. W. - McKelvey - Leigh D. - Wark, L. (1996): Nonresidential Father Involvement, Journal of Divorce \& Remarriage, 25(3-4), 1-14.

Pearson, J. - Thoennes, N. (1990): Custody after divorce: Demographic and attitudinal patterns. American Journal of Orthopsychiatry, 60(2), 233-249.

Seltzer, J. A. (1991): Relationships between Fathers and Children Who Live Apart: The Father's Role after Separation. Journal of Marriage and Family, 53(1), 79-101. doi:10.2307/353135

Shiller, V. M. (1986): Joint versus maternal physical custody for families with latency age boys: Family characteristics and child adjustment. American Journal of Orthopsychiatry, 56, 486-489.

Skevik, A. G. (2006): Absent fathers or reorganized families? Variations in father -child contact after parental break-up in Norway. Sociological Review, 54/1, 114132.

Spéder Zs. (2011): Ellentmondó elvárások között.... Családi férfiszerepek, apaképek a mai Magyarországon. In. Pongrácz T-né (szerk.): A családi értékek és a demográfiai magatartás változásai. KSH, Népességtudományi Kutatóintézetének Kutatási Jelentései 91: 129-149. 
Szepesházi P. (2010): A gyermektartásdíj megállapítása és behajtása egyes külföldi jogrendszerekben - a hazai adaptáció esélyei. Jogi tanulmányok, 2010. 14. évf. 3. sz.77-91.

Szalma, I. (2014): A gyermekvállalás társadalmi normái és a mesterséges megtermékenyítéssel kapcsolatos attitűdök vizsgálata Magyarországon és Európában. Replika (85-86) 35-57.

Takács J. (2017): Aktívan törődő apák. Szociológiai Szemle, 27(3), 104-126.

Takács J. (2019): How involved are involved fathers in Hungary? Exploring caring masculinities in a post-socialist context. Families, Relationships, and Societies. https://doi.org/10.1332/204674319X15592179267974

Visser, M. - Finkenauer, C. - Schoemaker, K. - Kluwer, E.S, - Rijken, R.V. - Lawick, J.V. - Bom, H. - Schipper, J.C. - Lamers-winkelman, F. (2017): I'll Never Forgive You: High Conflict Divorce, Social Network, and Co-Parenting Conflicts. Journal of child and family studies. 3055-3066.

Weiss E. (2000): Az új Polgári Törvénykönyv és a családjogi viszonyok szabályozása. PJK, 2000/2., 4-13. 